\title{
Osmanlı Medreselerini Islah Çabaları Üzerine Bir Değerlendirme*
}

\author{
Hasan Yıldı* \\ (ORCID ID: 0000-0002-9231-0158) \\ Makale Gönderim Tarihi \\ 16.01.2019 \\ Makale Kabul Tarihi \\ 22.03.2019
}

\section{Özet}

Osmanlı eğitim sisteminin zeminini oluşturan medreseler altı asra yaklaşan kurumsal ömrü sürecinde devlete ve topluma önemli hizmetlerde bulunmuş müesseselerdir. Devlet teşkilatının ve imparatorluğun asli unsuru olan Müslüman ahalinin intiyaçları esas alınarak kurulan ve yaygınlaştırılan medreselerde zaman zaman ortaya çıkan olumsuzluklar ve düzensiz uygulamalar nedeniyle ıslahat faaliyetlerinin gerçekleştirilmiş olması olağan bir durumdur. Islahat faaliyetlerinin gerekçesi olan kural dışı uygulamaları ve olumsuzlukları medreselerdeki bozulmanın ve gerilemenin başlangıı kabul ederek bunu üç asır boyunca devam ettiren akademik çalışmaların çokluğu dikkat çekmektedir. Bozulmayı ya da gerilmeyi tarihte yaşanmış bir olaya bağlamak, altı asırlık müktesebatı bağlamından kopararak parçacı bir bakış açısıyla ele almak, ayrıca mukayese ve değerlendirmeleri eşdeğer olmayan eğitim kurumları üzerinden gerçekleştirmek sağlıkı sonuçlara ulaşmayı engelleyen yaklaşımlardır.

Bu makalede altı asırlık kurumsal geçmişe sahip olan Osmanlı medreselerinde ıslahata duyulan ihtiyaç, ıslah çabaları ve sonuçları, bozulma ve gerilemenin yapısal bir sorundan kaynaklanıp kaynaklanmadığı, uygulayıcıların icraatlarının bozulmaya ve gerilemeye etkisinin hangi düzeyde olduğu hususları ele alınıp değerlendirilecektir.

Başta arşiv belgeleri olmak üzere dönemin yayın organları ve bilimsel çalışmalar taranmak suretiyle hazırlanan bu makaleyle Osmanlı medreselerine ilişkin sağıklı değerlendirmelerin yapılabilmesi amaçlanmıştır. Bu çerçevede, yaygın rivayetlerin aksine dönemsel bağlamı içerisinde medreselerin ve

\footnotetext{
* Bu makale Hasan Yıldız'ın "Dârü'l-hilâfeti'l-aliyye Medresesi'nde Eğitim ve Öğretim” isimli doktora tezinden üretilmiştir. (Bkz. Hasan YILDIZ, Dârü'l-hilâfeti'l-aliyye Medresesi'nde Eğitim ve Öğretim, İstanbul Üniversitesi Sosyal Bilimler Enstitüsü Felsefe ve Din Bilimleri Enstitüsü, Basılmamış Doktora Tezi, İstanbul-2017.

*Dr., MEB Maarif Müfettişi, hasanyildiz@meb.gov.tr.
}

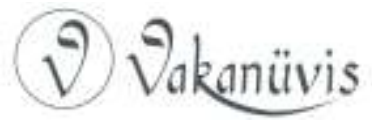


mensuplarının değişime ve gelişmeye açık tavırlar sergiledikleri ortaya çıkmaktadır.

Anahtar Kelimeler: Osmanlı Eğitim Tarihi, Osmanlı Medreseleri, Din Eğitimi, Islahat.

\section{An Evaluation on Reform Attempts in Ottoman Madrasahs}

\section{Abstract}

Madrasahs which set ground for Ottoman education system are institutions provided important services for both government and the society approximately six centuries throughout its institutional existence. It is quite predictable that reforms are made due to unsystematic implementations and occasionally occured problems in Madrasahs which are established and expanded based on needs of muslim community, which was a key factor of state organisation and the empire. The abundance of academic studies which had maintained it for three centuries by accepting irregular implementations and problems, that is the reason of reform activities, as a start of impairment and regression are noticeable. To link impairment and regression with an event occurred in the past, and to discuss six century long aquis by tearing apart from its context and approach as it is an independent piece, moreover, to make comparison and evaluation over non-equivalent educational institiutes are preventing approaches for good results.

In this article, needs of reform in Ottoman madrasahs which had six century long past, reform attempts and its results, whether impairment and regression are originated from structural matters, and how far implementers are effective in impairment and regression are evaluated and discussed.

The aim of this article, which was prepared by scanning archives and scientific studies of said period, is to make sound evaluations about Ottoman madrasahs. In this context, contrary to widwspread narratives, it is revealed that within the periodical context, madrasahs and those affined with them exhibited attitudes open to change and development.

Keywords: Ottoman Education History, Ottoman Madrasahs, Religious Education, Reform. 


\section{Giriş}

Osmanlı'da ilk medrese Hicri 731 (M.1330) yılında Orhan Gazi (H. 680-761) tarafından İznik'te açılmıştır ${ }^{1}$. Orhâniye Medresesi adı verilen bu medresenin ardından fetihlerle doğru orantılı olarak medrese sayısında hızı artışlar gözlenmiştir. Kuruluşla birlikte devam eden süreçte "bürokrasinin oluşması ve halka yönelik hizmetler verilmesinde birinci derecede müessir olan ${ }^{2 "}$ medreselerin, tertip, tedrisât ve nizâmâtını temin ${ }^{3}$ için bir takım düzenlemeler hayata geçirilmiştir. Bu düzenlemelerin ilki Sultan II. Mehmet (Fatih) döneminde gerçekleştirilmiştir. Bu dönemde uygulamaya geçirilen kânunnâmeyle "ilmiye mensuplarıyla devlet memurları arasındaki mertebeler tesbit edilerek, ilmiye sınıfının statüsü ortaya konulmuş ${ }^{4 \prime}$ ayrıca ilmiye sınıfının ve medreselerin dereceleri açık bir şekilde belirlenerek medreseden mezun olanların görevde yükselme basamakları açıklanmıştır ${ }^{5}$. İlmiye sınıfına ve medreselere ilişkin ihdâs edilen bahse konu düzenlemelerle, ilme ve ilim adamına gösterilen önemin yanında, ilmiye sınıfında ehliyet ve liyakatin; medreselerde ise tertip ve düzenin esas alınması amaçlanmıştır.

Medreseler için belirlenmiş olan dereceleri başarıyla tamamlayarak icazetname almaya hak kazanan talebeler, medreseden müderris namzedi olarak mezun olmakta ve matlab adı verilen deftere isimleri kaydedilerek müderrislik ve kadılık için sıra beklemektedirler ${ }^{6}$. Fatih'ten sonraki dönemlerde de pek çok ferman ve lâyiha yayınlanmak suretiyle Fatih Kanunnâmesi'nde belirlenmiş olan tertip

\footnotetext{
1 İsmail Hakkı Uzunçarşılı, Osmanlı Devletinin IIlmiye Teşkilâtı, Türk Tarih Kurumu Yay., Ankara, 2014, 4.bs., s.3.

2 Mefail Hızlı, "Anadolu'daki Osmanlı Medreseleri: Bir İcmal”, Türkiye Araştırmaları Literatür Dergisi, (2004) c.2, S. 4, s.372.

${ }^{3}$ Emin Bey, "Tarihçe-i Tarîk-i Tedris", Ilmiye Salnâmesi, Dârü'I-hilâfeti'l-Aliyye, MatbaaI Âmire, 1334, s.643.

${ }^{4}$ Halaçoğlu, XIV-XVII. Yüzyıllarda Osmanlılarda Devlet Teşkilâtı ve Sosyal Yapı, T.T.K. Yay., 7.bs., Ankara, 2014, s.141.

${ }^{5}$ Bkz. Kânunnâme-i Âl-i Osman, Tarih-i Osmanî Encümeni Mecmuasının ilâvesi, Ahmed ìnsan Şürekâsı Matbaacılık Osmanlı Şirketi, İstanbul, 1329, s.20.

${ }^{6}$ Uzunçarşılı, ilımiye Teşkilâtı, s.55.
}

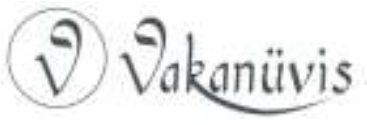


ve düzenin devamına ilişkin hükümler uygulamaya konulmuştur ${ }^{7}$. II. Meşrûtiyet döneminde girişilen ıslahat düzenlemelerinde de, Fatih dönemindeki bahse konu tertip ve düzene atıf yapılması dikkat çekicidir ${ }^{8}$.

$\mathrm{Bu}$ makalede 594 yıllık kurumsal tarihe sahip olan Osmanlı medreselerinde ıslahata duyulan ihtiyaç, ıslah çabaları ve sonuçları, bozulma ve gerilemenin yapısal bir sorundan kaynaklanıp kaynaklanmadığı, uygulayıcıların icraatlarının bozulmaya ve gerilemeye etkisinin hangi düzeyde olduğu hususları ele alınıp değerlendirilecektir. Yapılan alan taramasında mezkûr konular çerçevesinde pek çok yazı ve makalenin yayınlanmış olduğu; Türk eğitim tarihine ilişkin eserlerde bu konu için bölümler açıldığı görülmektedir. Bu yayınların büyük bir kısmının birbirini tekrar eden değerlendirmeler içerdiği, medreselerdeki bozulmanın başlangıcını ve gerilmeyi tarihte yaşanmış bir olaya bağlamayı ilke edindiği görülmektedir. Dolayısıyla altı asırlık müktesebata bütüncül bir yaklaşım yerine parçacı bir bakış açısıyla yaklaşılmış, ayrıca yapılan mukayese ve değerlendirmelerin eşdeğer eğitim kurumları üzerinden yapılmadığı müşahede edilmiştir. Konuya eleştirel açıdan yaklaşan Sarıkaya'nın Osmanlı Medreselerinin Gerileme Meselesi: Eleştirel Bir Değerlendirme Denemesi ${ }^{9}$ isimli makalesi ile Bolay'ın Osmanlılarda Düşünce Hayatı ve Felsefe ${ }^{10}$ isimli eseri medreseler hakkında alışıımış ve yerleşik hale gelmiş bakış açılarını sorgulamakta; kalıplaşmış tekrarları aşan önemli tespit ve değerlendirmelerle birlikte araştırmacılara yeni ve farklı bakış açıları sunmaktadır.

\section{Osmanlı Medreselerinde Islahata Duyulan İhtiyacı Doğuran Nedenler}

\footnotetext{
7 Uzunçarşılı, a.g.e., s.251.

8 Istanbul Müftülüğü Meşihat Arşivi (iMMA), Meclis-i Mesâlih-i Talebe Defterleri (MMTD, nr. 2203, s.3; Beyânü'l-Hak, S.15, s.322-324; Emin Bey, a.g.e., s.642,643; Hüseyin Atay, Osmanlılarda Yüksek Din Eğitimi: Medrese Programları-icazetnâmeler, Islahat Hareketleri, Dergah Yayınları, İstanbul, 1983, s.232; Emin Bey, a.g.e., s.642,643;

9 Yaşar Sarıkaya, "Osmanlı Medreselerinin Gerileme Meselesi: Eleştirel Bir Değerlendirme Denemesi", İslâmî Araştırmalar Dergisi, 1999, No:3, (s.23-39).

${ }^{10}$ S. Hayri Bolay, Osmanlılarda Düşünce Hayatı ve Felsefe, Akçağ yay., Ankara, 2005, s.20-48.
}

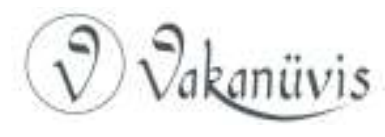




\section{Kural Dışı Uygulamalar}

Kanuni Sultan Süleyman dönemiyle birlikte, kânunnâme ve lâyihalarda ilmiye sınıfı ve medreseler için belirlenmiş olan düzenlemelere aykırı bazı taleplerin; başta padişah olmak üzere ulemâ ve saray erkânı tarafından gündeme getirildiği hususu yaygın olarak benimsenmiş iddialardandır. Örneğin Kanuni Sultan Süleyman'ın, kendisine güzel kasideler takdim eden Şair Bâkî(ö.1008/1600)'yi sıra bekletmeden mülâzım defterine kaydettirmesi ${ }^{11}$ kanuna muhalif uygulamanın en üst düzeydeki ilk örneği olarak gösterilmektedir*. Devlet erkânı ve ulemâ tarafından başlatılan kural dışı benzeri uygulamalar zaman içinde yaygınlaşarak, eğitim görmeden icâzet almak ve makam-mevki elde etmek isteyenlerin çoğalmasına yol açmıştır. Nitekim ilmiyede ilk imtiyaz Fenârî evlâdına verilmiş ${ }^{12}$, daha sonraki tarihlerde bu imtiyaz diğer ulemâ ve devlet erkânının ailelerine de tanınmak suretiyle yaygınlaşmıştır ${ }^{13}$.

Uzunçarşılı(1887-1977)'nın naklettiğine göre; XVI. yüzyıla ait bir medrese Kânunnâmesi'nde; "...medreseye devam edenlerin müretteb medrese tahsilini yapmadan bir yolunu bularak iltimas ile müderrislik ve kadılık için vilayetlerden istanbul'a mülâzemete geldikleri... ${ }^{14 "}$ hususuna dikkat çekilmiş, bu tesbitin ardından medreselerin derecelerinden bahsedilerek, talebenin ders gördüğü müderristen aldığı vesîkayı/icazetnâmeyi bir üst dersin müderrisine göstermeden derse kabul edilmeyeceği yönünde uyarıda bulunulmuştur ${ }^{15}$. "XVI asrın ikinci yarısında 29 Şevval 983/1 Şubat 1576'da İstanbul, Edirne ve

\footnotetext{
11 Uzunçarşılı, a.g.e., s.55.

* Bahse konu uygulamanın günümüzdeki örneğini "fahri doktora" unvanı verilmesi olarak değerlendirebiliriz. Çağdaş üniversitelerde resmiyet kazanan ve yaygın bir şekilde gerçekleştirilen bu uygulama ile örgün eğitim kurumlarında eğitim görmediği halde belirli bir alanda yetkinliğini ortaya koymuş şahısların değeri takdir edilmekte ve yetkin oldukları alanda kendilerinden yararlanılması amaçlanmaktadır. Günümüz için eleştirilmeyen bu uygulamanın bir benzerinin; dönemin padişahı Kanuni Sultan Süleyman tarafından gerçekleştirilmiş olması nedeniyle, medreselerdeki usulsüzlüğün başlangıcı addetmek doğru bir yaklaşım olarak değerlendirilmemektedir.

${ }^{12}$ Atâullah Nev'izâde Atâyi, Zeyl-ü Şakâyık li-Atâyi, y.y., t.y., s. 32.

${ }^{13}$ Bkz. Uzunçarşılı, a.g.e., s.80; Hüseyin Atay, "Medreselerin Gerilemesi", A.Ü.i.F. Dergisi, Ankara, 1981, S.24, s.32.

${ }^{14}$ Uzunçarşılı, a.g.e., s.18.

15 Uzunçarşılı, a.g.e.,19.
}

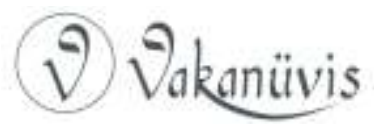


Bursa Kadılarına ve onlar vasıtasıyla müderrislere hitaben gönderilen bir fermanda medrese talebelerinin nizâmı bozulup istihkâkı olmayanların medrese derecelerini görmeden, süratle danişmend olarak mülâzim olmak sevdasıyla medrese kanununa aykırı yol aldıkları ${ }^{16 \prime \prime}$ hususuna dikkat çekilerek, medreselerin ders müddetleri Kânunnâme'de ayrı ayrı gösterilmiştir ${ }^{17}$. Medreselerde baş gösteren bu kanun dışı mülâzemet ${ }^{18}$ elde etme ya da yükselme çabalarının zamanla artarak devam etmesi, medrese eğitiminde bir takım usulsüzlüklerin yaygınlaşmasına ve yerleşik hale gelmesine yol açmıştır. Bu çerçevede "Osmanlı Medreseleri XVI. yüzyıldan itibaren bozulmaya başlamış, müderrislikler ve kadılıklar ehil olmayan kimselere rüşvet ve hatırla verilmeye başlanmıştır. Bu da ilmî seviyenin düşmesine ve Osmanlı Devleti'nin Avrupa'ya göre geri kalmasına yol açmıştır ${ }^{19 "}$ şeklinde genel değerlendirmeler yapılagelmiştir. Bu tür genellemelerde ifade edilen rüşvet ve iltimasın medreselerde görülmeye başlamış olması doğru bir tesbit olmakla beraber, mezkûr fiillerin Osmanlı́nın Avrupa'ya göre geri kalmasına yol açtığı şeklindeki iddianın ileri sürülmesi mâkul görülmemektedir. Medreseler İslami ilimlerin tahsil edildiği nev-i şahsına münhasır eğitim kurumları olması hasebiyle, Avrupa'daki eğitim kurumlarıyla mukayese edilme kabiliyeti mevcut değildir. Mukayesenin eşdeğer kurumlar arasında yapılmasının daha sağlıklı olacağı ilkesinden hareketle; Osmanlı medreselerinin Avrupa'daki eş değeri olsa olsa dînî eğitim veren okullardır. Dolayısıyla sadece medresedeki eğitim düzeyinden yola çıkılarak Osmanlı Devleti'nin Avrupa'ya göre geri kaldığı şeklinde bir yargıya varılması, kaba bir genellemeden ibarettir. Bahse konu fiillerin medreselere mâl edilmesi ve bu durumun medrese sistemine ilişkin bir arıza gibi değerlendirilmesi haksızlık olur ${ }^{20}$.

\footnotetext{
${ }^{16}$ Bkz. Uzunçarşıll, a.y.

17 Bkz. Uzunçarşılı, a.y.

18 Osmanlı ilmiye teşkilatında müderris olabilmek için medreseden mezun olduktan sonra belli bir süre yapılan staj. (ilhan Ayverdi, Kubbealtı Lügati: Asırlar Boyu Tarihi Seyri içinde Misalli Türkçe Sözlük, Kubbealtı yay., (gözden geçirilmiş) 3.bs., İstanbul, 2008, s.2228.

${ }^{19}$ Halaçoğlu, a.g.e., s. 143.

${ }^{20}$ Ayr. Bkz. Yaşar Sarıkaya, a.g.m., s.23-39.
}

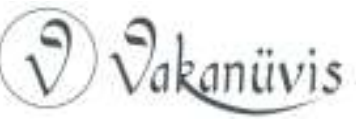


Medreselerdeki bozulmanın XVI. yüzyılın sonlarına doğru başladığını belirten Uzunçarşılı, daha önceki yıllarda vukû bulan usulsüzlükleri münferit ve nadir vakalar olarak değerlendirmektedir ${ }^{21}$. Tarihçilerin, Osmanlı müesseslerinde XVI. yüzyılın ikinci yarısında başladığı konusunda ittifaka vardıkları umûmî bozulmadan nasibini alan ilmiye teşkilatının"22, "hem müderris kalitesi itibariyle ve hem de tedrisât ve talebe cihetiyle 23 " maruz kaldığı etkinin yıllar geçtikçe artarak yerleşik hale geldiği dikkate alınırsa; medreselerde sistem kaynaklı bir bozulmanın değil uygulayıcılardan kaynaklanan bir bozulmanın baş gösterdiği anlaşılmaktadır. Nitekim Fatih Kânunnâmesi'nde ilmiye mensuplarının ve medreselerin derecelerinin belirlenerek, medreseden mezun olan müderrislerin görevde yükselme basamaklarının açıklanmış olması, bozulmanın kânunnâme dışı uygulamalardan kaynaklandığına açıkça işaret etmektedir. Kaldı ki medreselerin bozulması ve gerilemesine ilişkin olarak Osmanlı tarihçilerinin bahse konu somut örneklerden yola çıkarak ortaya koydukları görüşlerin tamamı medrese sistemine ilişkin olmayıp, uygulayıcıların gerçekleştirmiş oldukları: Rüşvet, iltimas, adam kayırma, ehliyetli ve liyakatli olmayanların sistem dışı terfi ve tayinleri, imtiyazlı sınıf oluşturulması ve benzeri fiillere yöneliktir. Netice itibariyle getirilen eleştirilerin medresenin sistematik yapısına ilişkin olmadığı; aksine yöneticilerin ve ilmiye mensuplarının kural dışı fiil ve davranışlarına ilişkin olduğu anlaşılmaktadır.

Öte yandan ilmiye mesleğinin saygınlığını korumak, liyâkat ve ehliyeti olmayan kimselerin bu seçkin mesleğe girmesini önlemek için,

\footnotetext{
${ }^{21}$ Bkz. Uzunçarşılı, a.g.e., s.75; Cahid Baltacı, XV-XVI Yüzyıllarda Osmanlı Medreseleri, IFAV yay., 2.bs., İstanbul, 2005, C:I., s.150.

${ }^{22}$ Mehmet İpşirli, "Osmanlı İlmiye Mesleği Hakkında Gözlemler (XVI-XVII. Asırlar)", Osmanlı Araştırmaları VII-VIII, edit. I.E. Erünsal, C.Ferrard, C.Woodhead, İstanbul, 1988, s.274; (Medreselerdeki bozulmanın; devletin zayıflamasıyla doğru orantılı olarak başladığını ileri süren Bayram Kodaman 17'nci asırdan, Şerif Mardin ise bozulmayı ulemâya yüklemek suretiyle $18^{\prime}$ inci asırdan başlatmaktadır. Adnan Adıvar'a göre medreselerdeki gerileme 17'nci yüzyıldan itibaren aklî ve müsbet ilimlerin gözden düşmesiyle başlamıştır. Bkz. Bayram Kodaman, Abdülhamid Devri Eğitim Sistemi, T.T.K. Yay., Ankara, 1999, s.X; Şerif Mardin, Türkiye'de Toplum ve Siyaset, Iletişim yay., 13.bs., İstanbul, 2006, s.161; A.Adnan Adıvar, Osmanlı Türklerinde Illim, Remzi Kitabevi, 4. Baskı, İstanbul, 1982.s.126.
}

${ }^{23}$ Uzunçarşılı, IIImiye Teşkilâtı, s.75.

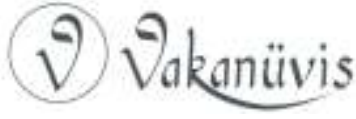


önceki ulemâ tarafından getirilmiş olan imtihan usulünün sadece öğrencilere mahsus kılınması da ${ }^{24}$ bozulmanın önemli sebeplerindendir. Yine müderrislerin görevlerini nâipler/vekiller eliyle yürütmeleri ve böylece tevcih tarikinin* yok sayılarak ihlâl edilmesi, ayrıca tarik dışı tayinler nedeniyle alt derecedeki medreselerde yığılmaların olması medreselerdeki bozulmanın artmasına yol açan sebeplerdendir ${ }^{25}$.

Medreselerdeki düzeni ilk defa bozmaya çalışanların idareciler, saray ve padişah olduğunu dile getiren Atay, bozulmanın sorumluluğunun üst kademeye bırakılması gerektiğini belirtir ${ }^{26}$. Genel bir değerlendirmeyle, medreselere kânunnâme dışı müdahalelerin yapılması, bazı ulemâzâdelere 15 yaşından evvel müderrislik rüûsu verilmesi, talebelerin para ve rüşvet ile müretteb tahsil görmeden müderris olması, mürettep tahsil gören liyakatli mülazımların yerine iltimaslıların öncelikle müderrisliğe tayin edilmesi ${ }^{27}$ gibi uygulamalar makam ve mevki sahibi kimselerin kural dışı müdahalelerini ifade etmektedir.

Uzunçarşıı, ilmiyede iltimasın başlangıcını II. Bâyezid'in bir müdahalesine dayandırmaktadır ${ }^{28}$. Padişahın imtiyazına mazhar olması nedeniyle "Zamirî" mahlasıyla anılan Hamza Nureddin adındaki müderrisin, II. Bâyezid (ö.918/1512) tarafından Sahn-ı Semân Medresesi'ne müderris tayin edilmek istenmesi üzerine, ilmî yetersizliğini gerekçe göstererek bu tayine mâni olmak isteyen dönemin kazaskeri Mevlana Müeyyedzâde Abdurrahman Efendi(ö.922/1516)'nin, II. Bâyezid'in ısrarı üzerine, bu zâtın müderris olarak tayin edilmesine mecbur kalması; tarihî kayıtlara düşen ilk önemli örnek olarak kabul edilmektedir ${ }^{29}$.

Yine Şeyhülislam ỉbn Kemal(ö.940/1534)'in, Vezîriâzam Makbul İbrahim Paşa(ö.942/1536) nezdindeki tavassutuyla, Müeyyedzâde'nin

\footnotetext{
${ }^{24}$ Bkz. Emin Bey, a.g.e., s. 649

* Tâyin ve terfî sistemi.

${ }^{25}$ Emin Bey, a.y.

${ }^{26}$ Hüseyin Atay, Osmanlılarda Yüksek Din Eğitimi, s.155.

27 Uzunçarşılı, ilımiye Teşkilâtı, s.76.

${ }^{28}$ A.y.

${ }^{29}$ Taşköprîzâde Ahmed ibn Mustafa, Tercüme-i Şakâyık-ı Nu'mâniyye, y.y., t.y. s.347.
} 
oğlu Abdülvehhab Efendi'nin kanun hilâfına müderris olarak tayin edilmesi; ayrıca Fenârîzâde evladına kırk akçe yevmiyeli medreselere doğrudan tayin edilme ayrıcalığı tanınması ${ }^{30}$, medreseler için belirlenen nizamın bozulmasının yanında, müderris ve talebe açısından da nitelik kaybına yol açmışır. İltimaslar yeni iltimaslara kapı aralamış, gerek müderrislikte gerekse talebelerde mürettep nizamın dışına çıkma yolunda çaba ve gayretler artarak devam etmiştir.

ilttimasın saray merkezli olması da dikkati çeken bir durumdur. Sahn-ı Semân bânîsi Fatih'in, bir düzen tesisi amacıyla çıkardığı kânunnâmede, ilmiye sınıfı için belirlediği liyâkat, ehliyet ve kıdeme ilişkin ilkelerin; yine onun halefleri tarafından göz ardı edilerek az da olsa istisnâî uygulamalara sebebiyet verilmesi, diğer makam ve mevki sahiplerinin de bu yola tevessülüne kapı aralamıştır. Nitekim Uzunçarşılı, bazı padişahların, saray mensuplarının tesiriyle Hatt-ı Hümâyun göndermek suretiyle ehliyet ve kıdem aranmadan bazı şahısların kıdem ve liyakatleriyle mütenasip olmayan müderrisliklere tayin edildiğini belirtmektedir ${ }^{31}$.

Gelibolulu Mustafa Âli(ö.1008/1600), Künhü'l-Ahbâr isimli eserinde, medreselerdeki inmâl ve liyakatsizliğin sebebini mevâlizâdelerin meydan almasına bağlamaktadır ${ }^{32}$. Öte yandan müderrislerin ilmî düzeyindeki düşüşe işaret eden Asâfnâme sahibi Lütfi Paşa(ö.1564) ise, müderrislerin ve ulemânın birbirlerine haset üzere olduklarını, dolayısıyla derecelerinin araştırılarak; ulemânın ileri gelenlerine danışmak lazım geldiğini belirtmektedir ${ }^{33}$. Netice itibariyle o döneme ilişkin yapılan her iki tesbitin, birbirini teyit eder mahiyette olduğu anlaşılmaktadır. Tertip dışı mülâzemet ve müderrislik elde etme girişimleri, ilmiye câmiasının nitelik ve kalitesini düşürmenin yanında, başta huzursuzluk olmak üzere haset ve benzeri olumsuz duygu ve düşüncelerin yaygınlaşmasına da sebebiyet vermektedir.

\footnotetext{
30 Uzunçarşılı, IImiye Teşkilâtı, s.76-77.

31 Liyakât ve kıdeme uyulmadan gerçekleştirilen müderris atamalarına ilişkin örnekler için Bkz. Uzunçarşılı, Ilmiye Teşkilâtı, s.76-78.

${ }^{32}$ Nakl. Uzunçarşılı, a.g.e., s.76.

${ }^{33}$ Mübahat S. Kütükoğlu, Lütfü Paşa Âsafnâmesi (Yeni Bir Metin Tesisi Denemesi), İstanbul Üniversitesi Edebiyat Fakültesi Basımevi, İstanbul, 1991, s.16; Ayr. Bkz. Dr. Rudolf Tschudi, Das Asafnâme Des Lutfi Pascha, (içinde) Asafnâme-i Vezir Lütfi Paşa, Mayer\&Müller, Berlin, 1910, (Osmanlıca metin bölümü) s.16,17.
}

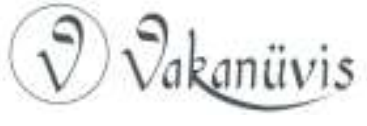


Gelibolulu Mustafa Âli'nin, -III. Murad devrinde- 1581 de kaleme aldığı Nushatü's-selâtîn isimli eserinde, bu dönemde ilmiyede gerçekleşen kötü uygulamalara örnek olarak, "ilim alanında adam kayırıması, bir kadılık veya müderrislik boşaldığında liyâkat yerine adayın hangi devletlünün adamı olduğuna bakılması" gibi hususları saymakta, "bunu önlemek için imtihanların ciddi tutulması gerektiği" yönündeki teklifini dile getirmektedir ${ }^{34}$. Bir diğer bozukluk ise bilhassa kadılıklarda değişik isimler altında da olsa rüşvetin cârî olmasıdır. Kadılar mansıp almak için verdiklerini ziyadesiyle, göreve başladıktan sonra yazdıkları hüccet ve tezkirelerden almağa çalışmaktadırlar ${ }^{35}$.

Koçi Bey(ö.1650) tarafından 1631 yılında hazırlanarak Sultan IV. Murad'a sunulan risâlede ise: Önceki dönem ulemâsı ile devrin ulemâsı mukayese edilmek suretiyle aradaki fark ortaya konulmuş; daha önce ilmiye mesleğinde benimsenmiş olan tertip ve düzene riayet edilirken, Hicri-1003 (Milâdî-1594) yılından itibaren bu tertip ve düzenin dışına çıkılarak liyakat sahibi olmayanların rüşvet ile değişik makamlara getirildiği, bu durumun ise ilmiye mesleğinde bozulmalara yol açtığı hususu dikkatlere sunulmuştur. Koçi Bey'in, Hicri-1003 yılını ilmiyedeki bozulmanın başlangıcı olarak alması; mezkûr tarihten önce Şeyhülislâm olan Sun'ullah Efendi'nin birkaç defa gereksiz yere azledilmesini ve yerine geçenlerin ise azledilme korkusuyla hakikati söylemekten çekinerek herkese hoş görünmeye çalışmalarına bağlamaktadır. Çözüm yolu olarak; "Menâsib-ı ilmiye, şefâatle verilmek revâ değildir." ilkesini hatırlatan Koçi Bey, ilim pâyelerinin verilmesinde iltimas ve torpil yerine, temel ölçüt olarak "ilim" kriterinin esas alınması gerektiğini; yaşa, kıdeme, soy ve sopa göre ilmî makam ve mevkîlerin verilmesinin doğru olmadığını, yaşanan tecrübelerden yola çıkarak izah etmektedir ${ }^{36}$.

Osmanlı tarihçisi Koçi Bey, ilmiyedeki bozulmayı Sultan III. Murad'ın saltanatının (1574-1595) son yılından itibaren başlamakta, devlet müesseselerindeki bozulma ve çözülmenin başlangıcını ise Kanuni

\footnotetext{
${ }^{34}$ Nakl. İpşirli, Osmanlı Ilmiye Mesleği Hakkında Gözlemler , s.275.

${ }^{35}$ A.e. , s.274.

${ }^{36}$ Bkz. Koçi Bey Risâlesi, Kütüphane-i Ebu'z-Ziya, 1.bs., Kostantiniyye, 1303, s.36-46; Yılmaz Kurt, Koçi Bey Risâlesi, Akçağ Yay., 3.bs., Ankara, 2011, s.11.
}

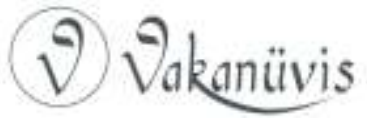


Sultan Süleyman dönemine kadar götürmektedir ${ }^{37}$. Nitekim ilmiyedeki bozulma, insan gücü kaynağının önemli bir kısmını medreselerden temin eden devlet müesseselerini doğrudan etkilemekte; devlet müesseselerindeki bozulma ise ilmiyenin tertip ve düzeninin bozulmasını artırmaktadır.

\section{Aklî ilimlerin Programdan Çıkarılması}

Taşköprîzâde(ö.968/1561) daha 1540'larda skolastik ilâhiyat ve matematiğin medrese ulemâsı arasında eski itibarını yitirdiğinden ve ilim düzeyinin düştüğünden yakınarak, kuramsal ilimler üzerine yazılmış kitapların rağbet görmediğinden, ulemânın da yalnızca basit el kitapları okuduktan sonra kendilerini âlim saydıklarından şikâyet etmektedir ${ }^{38}$.

Yine, Kâtip Çelebi'nin (ö.1067/1657) ileri sürmüş olduğu "Sultan Fatih tarafından medreselere konulan derslerin 'felsefiyyâttır' diye medreselerden kaldırılması ${ }^{39 "}$ diğer bir ifadeyle "aklî ve felsefî ilimlerin ders programlarından çıkarılması" da medreselerin bozulması ve gerilemesi hususunda yaygın şekilde benimsenen gerekçeler arasında yer almaktadır. Ancak Sahn medreselerinin kuruluşundan XVI. asrın sonlarına kadar yazılan eserlerin sadece \% 8,1'nin akli ilimlere ait olmas ${ }^{40}$ Fatih döneminde ve sonrasında da bu sahaya olan ilginin aynı düzeyde kaldığını göstermektedir. Bu dönemi diğer dönemlerden ayıran en önemli özellik olarak kısmî de olsa aklî ilimlere yer verildiği yönündeki tesbit dikkate alındığında ${ }^{41}$ : Tüm devirlerde medreselerde ağırlıklı olarak i̇slâmî ilimlerin okutulduğu, dolayısıyla dönemler arasında önemli bir farkın olmadığı kanaati hâsıl olmaktadır. Ders programlarında İslâmî ilimlere ağırlık verilmesi "devletin ve cemiyetin ihtiyaçlarının doğrudan karşılanması esasına, yani pratik faydacılık esasına dayanmaktadır ${ }^{42}$. Diğer bir ifadeyle, medrese sisteminin genel

\footnotetext{
37 Ömer Faruk Akün, "Koçi Bey", TDV islam Ansiklopedisi, c.26. s.143-148.

38 Halil İnalcık, Osmanlı Imparatorluğu-Klasik Çağ (1300-1600), Çev. Ruşen Sezer, Yapı Kredi Yay., İstanbul, 2003, s.187.

${ }^{39}$ Kâtip Çelebi, Mizânü'l-Hakk fí ihtiyâri'l-Ehak,2.bs.,Ali Rıza Efendi Matbaası, İstanbul, 1286, s.8,9.

${ }^{40}$ Fevzi Günüç, Türk Kültür ve Medeniyet Tarihinde Fatih Külliyesi-I, edit. Hüseyin Kutlu, IBB Kültür AŞ.yay., İstanbul, 2007, s.178.

${ }^{41}$ Günüç, a.g.e., s.179.

${ }^{42}$ Günüç, a.g.e., s.178.
}

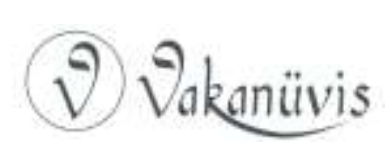


devlet işlerine faydalı olacak şekilde imparatorluk tarafından sistematik hale getirilerek geliştirilmesi ${ }^{43}$ zamanın ihtiyaçlarına göre düzenlemelerin yapıldığına işaret etmektedir. Dolayısıyla medreselerin gerilemesinin ve bozulmasının başlangıcı kabul edilen XVI. yüzyılın sonu itibariyle devlet işlerindeki çeşitliliğin ve farklı alanlarda yetişmiş elemanlara olan ihtiyacın artmasıyla doğru orantılı olarak medresenin de geliştirilmesi icap ederken; bunun gerçekleşmemiş olması, medresenin gerilediğine ya da bozulduğuna değil; kendisini yenileyemediğine ve geliştiremediğine delil teşkil etmektedir. Yine gerileme dönemi olarak isimlendirilen süreçte akli ilimler kapsamımda Felsefe'nin ders programlarından çıkarılması gerekçe gösterilse de S. Hayri Bolay'ın Osmanlılarda Düşence Hayatı ve Felsefe isimli eserinde: "Osmanlı'da her devirde felsefe olduğu" sonucuna varmış olması ${ }^{44}$ bu gerekçenin de tartışılabilir olduğunu göstermektedir. Kaldı ki Kâtip Çelebi'nin Mizânü'l-Hakk isimli eserinin baş tarafında ileri sürülmüş olan "Felsefenin medrese programından çıkartıldı̆̆ı" şeklindeki iddia kitabın sonsöz bölümünde bizzat kendisi tarafından tekzip edildiği de görülmektedir ${ }^{45}$.

Gerileme ve bozulma sebeplerinin iki ana başlık altında toplandığı dikkate alınırsa; bunlardan rüşvet ve iltimas gibi fiillerin kanunlara aykırı davranışlar olduğu açıktır. Akli ilimler olarak nitelenen: Hesap, hendese, hey'et, hikmet gibi ilimler ise medreselerin kuruluşundan kapatııı̧ına kadar geçen süreçte "yardımcı ilimler" olarak varlıklarını devam ettirmişlerdir" ${ }^{46}$. Medreseler esas olarak İslâmi ilimlerin tedris edildiği eğitim kurumları olması hasebiyle bu ilimlerden; Fıkı ilmi kapsamında hesap, hendese, hey'et ve hikmet gibi yardımcı ilimlerden, Kelâm ilmi kapsamında ise Felsefe'den ister istemez yararlanmak durumundadırlar. Medreseler, vakıflar eliyle ve mütevelli tarafından yönetilen özerk kurumlar olması nedeniyle tek bir merkezden idare edilmemekte; dolayısıyla temel dersler aynı olsa da vakıf sahibinin ya da mütevellinin belirlemiş olduğu ders programı uygulamaya

\footnotetext{
${ }^{43}$ Şerif Mardin, a.g.e., s.28.

${ }^{44}$ Hilmi Yavuz, Türkiye'nin Zihin Tarihi, Timaş Yay., İstanbul, 2013, 3.bs., s.62; Bkz. S. Hayri Bolay, Osmanlılarda Düşünce Hayatı ve Felsefe, s.20-48.

${ }^{45}$ Bolay, a.g.e., s. 20

${ }^{46}$ Yaşar Sarıkaya, a.g.m., s.23-39.
}

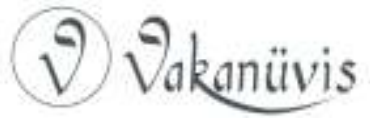


geçirilmektedir ${ }^{47}$. Tedrisatın muhtevası ve usulü ile medresenin idaresi konusunda müderris ve mütevellinin sorumluluğu bulunmaktaydı. Bu haliyle medreseler yönetim bakımından mahallî; denetim bakımından merkeziyetçi bir anlayışla işletiliyorlard $\iota^{48}$. $18^{\prime}$ inci asrın sonlarına kadar devlet, eğitim-öğretim işlerine ve medreselerin tesisine resmi olarak karışmaz ve bu işler hükümetin görevleri arasında sayılmazdı. Eğitimöğretim faaliyetleri daha çok vakıflar eliyle yürütülürdü ${ }^{49}$. Devlet medreselerdeki eğitimden ziyâde mezunların iş hayatını düzenlemeye gayret ediyordu. Programların düzenli olarak uygulanması ile ilgili hazırlanan az sayıdaki kanunnameyi uygulayacak resmi bir makam da mevcut değildi ${ }^{50}$. Bu nedenle bir medresede gözlenen usulsüz ya da hatalı bir uygulamayı medreselerin tümüne teşmil etmek ve bunu sistemsel bir problem olarak değerlendirmek doğru görülmemektedir. Bu noktada 1691 yılında İstanbul'da bulunduğunu belirten İtalyan Graf Marsilli(1658-1730)'nin Osmanlı toplumunun ilmî düzeyine ilişkin tespitleri dikkat çekicidir. Marsilli, Türklerin eğitim ve öğretim faaliyetlerini temrin ve alıştırma yapmak suretiyle yürüttüklerini, Osmanlı tebâsının yaşadığı diğer şehir merkezlerinde ilim ve fenle meşgul olanlar arasında üç dil bilmeyen kimsenin hemen hemen olmadığını, ilk sırada dinî ilimler tahsil edildikten sonra kendilerini geliştirmek isteyenlerin nesir ve nazım olarak yazı yazmayı öğrendiklerini, bununla birlikte Mantık ve Felsefe ile tıbbî ilimlere çok önem vererek çalıştıklarını belirtmektedir. Kimya ilmini çok seven Türklerin Hendese ve Kozmografya'ya çok rağbet gösterdiklerini ve Coğrafya ilminde de çok malumat sahibi olduklarını dile getirmektedir. Kitaplara çok değer veren Türklerin, İstanbul'da 90 bin kadar hattat, yazıcı veya müstensihin bulunması nedeniyle, bu kişilerin ekmeğine mani olmamak adına kitapların basılmasını arzu etmediklerini; yoksa matbaanın dinen haram olduğuna ilişkin bir yaklaşımlarının kesinlikle bulunmadığını beyan etmek suretiyle Osmanlı ahalisinin ilme ve fenne

\footnotetext{
${ }^{47}$ Ayr. Bkz. Kodaman, a.g.e., s.X.

48 Yaşar Sarıkaya, Medreseler ve Modernleşme, İz Yayıncılık, İstanbul, 1997, s.32.

${ }^{49}$ Emrullah Efendi, Osmanlı İttihad ve Terakki Cemiyyetinin Bin Üç yüz Yirmi Yedi Senesi Dördüncü Konferansında Tanzim Olunan Siyasi Programa Dair Izahnâme, Matbaa-ı Hayriyye, Kostantiniyye,1330, s.76.

50 Mustafa Ergün, "Batılılaşma Dönemi Osmanlı Eğitim Sistemine Mukayeseli Bir Bakış", Osmanlı Dünyasında Bilim ve Eğitim-Milletlerarası Kongresi Tebliğleri (Istanbul 12-15 Nisan 1999), Derleyen: H.Yavuz Türkoğlu, iRCiCA yay., İstanbul, 2001, s.93.
}

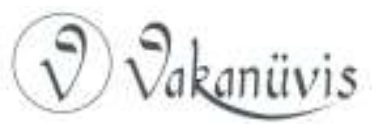


verdiği önemi ve rağbeti çarpıcı bir üslupla ifâde etmektedir ${ }^{51}$. Marsilli'nin Osmanlı'da ilme ve fenne verilen önem bağlamında ortaya koymuş olduğu mezkûr değerlendirmeler, ilmiye sınıfının kaynağı olan medreselerde verilen eğitimin düzeyini ve kalitesini göstermesi açısından önemlidir. Türklerin bazı özelliklerine ilişkin ağır ve haksız eleştirilere de kitabında yer vermiş olan Marsilli'nin ${ }^{52}$, ilmiye sınıfına ve ilme verilen ehemmiyete ilişkin olarak Türklerden övgüyle bahsetmiş olması; ortaya koymuş olduğu tesbitlerin gözleme dayalı olduğunu açıkça göstermektedir. Kaldı ki Türklere yönelik ağır ithamlar da bulunan yabancı bir yazarın, tanık olmadığı hususları Türkler lehine övgü dolu cümlelerle ifade etmesinin makul ve izah edilebilir bir tarafı da bulunmamaktadır. Netice itibariyle 17 'nci yüzyılın sonlarında Osmanlı'da aklî ilimlere verilen önemin İtalyan Marsilli tarafından hayranlıkla ifade edilmiş olması, bu ilimlerin yaygın bir şekilde medreselerde öğretildiğine en önemli kanıt niteliği taşımaktadır. Yine aynı zamanda bir papaz olan ve 1675 yılında İstanbul'u ziyaret ederek altı ay gibi bir sürede Türkiye'de kalarak seyahatlerde bulunmuş olan İngiliz seyyah George Wheler(1651-1724)'in, İstanbul'da Türkçe, Arapça ve Acemce ilmî elyazmaların alınıp-satıldığı bir çarşının bulunmasından ve imparatorluğun büyük şehirlerinin hepsinde geometri ve daha başka ilimleri öğreten hocaların mevcudiyetinden dolayı çok şaşırdığını dile getirmiş olması da bu durumu teyid eden bilgilerdendir ${ }^{53}$.

Öte yandan İshak b. Hasan Tokâdî(ö.1100/1688), Manzûme-i Tertîbi Ulûm isimli eserinde Hesap, Hendese, Hey'et, Astronomi ve Kimya gibi aklî ilimler ile Mantık, Lügat, Sarf ve Nahiv gibi alet ilimlerinin medrese müfredâtı arasında yer aldığını belirtmektedir. Yine Saçaklızâde Muhammed b. Ebu Bekir el-Marâşi (ö.1145/1732) tarafından 1128/1715 yılında yazılmış olan Tertibu'I-Ulûm* isimli

${ }^{51}$ Graf Marsilli, Osmanlı Imparatorluğunun Zuhur Ve Terakkisinden Inhitatı Zamanına Kadar Askeri Vaziyeti, çev. M. Kaymakam Nazmi, Büyük Erkânı Harbiye Matbaası, Ankara, 1934, s.26,47-49.

52 Marsilli, age., s. 45,46,51.

${ }^{53}$ Harold Bowen, Türkiye Hakkında Ingiliz Tetkikleri, çev. Orhan Burian, TTK. Yay., Ankara, 2011, s.18.

* Pek çok kütüphanede yazma nüshası bulunan bu eserin bazı nüshaları Risâle fíTâ'dâdi'l- Funûn ve Hakâiku'l-Ulum ve Tertîbu'l-Ulûm adını taşımaktadır. (Bkz. İbrahim

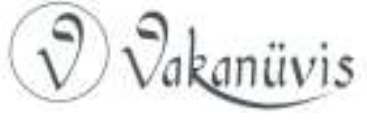


eserde de mezkûr ilimlere yer verildiği görülmektedir. Saçaklızâde, medreselerde sadece belirli metin, şerh ve hâşiyelerin okutulmasına karşı çıkmak suretiyle ders kitaplarının yeniden yazılmasının gerektiğini savunmakta; şerh ve haşiyelerle yetinilmesine karşı çıkmaktadır ${ }^{54}$. Saçaklızâde, mezkûr eserinde dönemin eğitim-öğretim sistemine ilişkin pek çok öneri sıralamaktadır. Çağına göre oldukça ileri düzeyde reformist bir eğitim zihniyetine sahip olan Saçaklızâde'nin yazmış olduğu eserde, eğitimde öğrenci odaklı bir anlayış ile birlikte program merkezli eğitim sürecinin önerilmiş olmasi ${ }^{55}$ içinde bulunulan dönemde medreselerde yenileşmeye ve yeni düzenlemelere duyulan ihtiyacı göstermesi açısından önemlidir.

Ayrıca 18 'inci yüzyıl âlimlerinden Ali b. Abdullah el-Uşşâkî(ö.12001785/1786)'nin kaleme almış olduğu Kaside fi'l-Kütübi'l-Meşhûre fi'lUlûm isimli eserinde, medreselerde okutulan dersler arasında aklî ilimler ile diğer alet ilimlerine yer verildiği görülmektedir ${ }^{56}$. 18'inci yüzyılda medreselerde uygulanan ders programına ilişkin resmî nitelikteki en önemli eser ise Fransa'nın talebi üzerine Reisülküttaplık tarafından hazırlatılarak 1742 'de Fransa'ya gönderilmiş olan Kevâkib-i Seb'a isimli risâledir. Bu risâlede, Osmanlı medreselerinde alet ilimleri kapsamında Sarf, Emsile, Bina, Maksûd, İzi, Merâh ve Şâfiye gibi pek çok eserin okutulduğu; Mantık, Âdâbu'l-Bahs ve Münâzara, Beyân ve Bediî gibi alet ilimleriyle beraber Isagoji, Felsefe, Hesap, Hendese ve Astronomi'ye ilişkin aklî ilimlerin de medrese programında yer aldığına dair açıklamalara yer verilmiştir ${ }^{57}$. Yukarıda zikredilen eserlerden biri hariç tamamının 18 'nci yüzyılda kaleme alınmış olduğu, Manzûme-i Tertîb-i Ulûm isimli eserin ise 17'nci yüzyılın sonuna doğru yazılmış olduğu dikkate alınırsa; $16^{\prime} \mathrm{ncı}$ yüzyılın sonlarından itibaren akli ilimlerin ders programlarından çıkarıldığına ilişkin iddiaların gereceği

Çetintaş, "Saçaklızâde Muhammed Mar'aşi”, Doğu'dan Batı́ya Düşüncenin Serüveni, edit. Bayram Ali Çetinkaya, 10c., İnsan yay., İstanbul, 2015, c.8, s.973.)

54 Ömer Özyılmaz, Osmanlı Medreselerinin Eğitim Programları, Kültür Bakanlığı yay., Ankara, 2002, s.21-39.

55 ibrahim Çetintaş, a.g.m., s.985-987.

56 Ömer Özyılmaz, a.g.e., s.21-39.

${ }^{57}$ Nasuhi Ünal Karaarslan, XVIII. Asrın Ortalarına Kadar Türkiye'de Ilim ve IIImiyeye Dair Bir Eser- Kevâkib-i Seb'a Risâlesi, TTK. Yay., Ankara, 2015, s. 14-46; Özyılmaz, a.g.e., s.37-39.

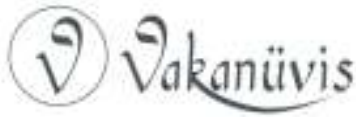


yansıtmadığı sonucuna ulaşılmaktadır. Ders programlarında aklî ilimlere yer verilmiş olmasına rağmen bu derslerin okutulmamış olması; ya müderrislerin ya da medrese tüzel kişiliğinin münferit inisiyatifleriyle bu yönde tercihte bulunulmalarından kaynaklanmaktadır. Yani aklî ilimlere karşı sistemsel ve topyekûn bir karşı duruş olmamakla birlikte müderrislerin veya medreselerin bu yöndeki bireysel ve mahalî̂ uygulamalarına tanık olan tarihçi ya da müelliflerin genelleme yapmak sûretiyle bahse konu hususların tüm medreselerde cârî olduğu şeklindeki algıya yol açtıkları anlaşılmaktadır. Öte yandan bahse konu mahallî uygulamaların, ilerleyen zamanlarda medreselerin tamamında olmasa bile bir kısmında yaygınlaşarak teâmül haline gelmiş olması da mümkündür.

1839-1924 tarihlerini kapsayan ve Tanzimat'tan Cumhuriyet'e Osmanlı eğitiminin sayısal verilerinin ortaya konulduğu istatistiksel bir çalışmada; medreselerin XIX. yüzyılın başına kadar son derece önemli bir işlev gördüğü, ancak XIX. yüzyılın başından itibaren değişen toplumsal ihtiyaçlara cevap veremez hale gelmeye başlaması nedeniyle gözden düştüğü bilgisine yer verilmiş olmas ${ }^{58}$, medreselerin Tanzimat dönemine kadarki süreçte göz ardı edilemeyecek olan rolüne işaret etmektedir. Kaldı ki medresenin kurumsal yapısının ve eğitim potansiyelinin, anılan dönem itibariyle toplumun değişen ihtiyaçlarına cevap veremez hale gelmiş olması üzerine medresenin yeniden ihyâsı ve çağa uygun hale getirilmesi gerekirken; "ulemâ ve medresenin, önce eğitim alanından sonra yönetim hizmetlerinden dışlanması ${ }^{59 "}$ ya da diğer bir ifadeyle gözden çıkarılması mânidardır.

Netice itibarıyla Tanzimat'a kadarki süreçte medreseye yöneltilen ve birbirinin benzeri olan eleştirilerin büyük oranda medresenin kurumsal varlığına yönelik olmayıp sadece usulsüz uygulamalar kapsamında: Rüşvet, iltimas, ehliyet ve liyâkat dışı atama gibi uygulayıcılardan kaynaklanan tasarruflara ilişkin olduğu ya da aklî ilimlerin ders programlarında yer almış olmasına rağmen bu derslere önem vermeyen zihniyete ilişkin olduğu anlaşılmaktadır. Ancak

\footnotetext{
58 Mehmet Ö. Alkan, Tanzimat'tan Cumhuriyet'e Modernleşme Sürecinde Eğitim Istatistikleri (1839-1924), T.C. Başbakanlık Devlet İstatistik Enstitüsü, Ankara, Kasım2000, s.XVIII.

${ }^{59}$ A.y.
}

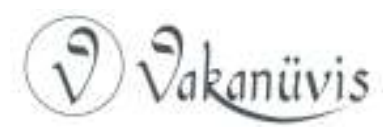


Tanzimat'la birlikte batı tarzı mekteplerin yaygınlaşarak çeşitlenmesi üzerine eleştiriler nitelik değiştirerek medresenin kurumsal yapısını hedef almaya başlamıştır. Mektep-medrese ikiliğine yol açan süreçte, mektepler hızlı bir şekilde gelişmiş; medreseler ise yeterli desteği alamadığı için güç kaybına uğramıştır. Müslüman toplumun bütünlüğünü az veya çok muhafaza eden mevcut eğitim sisteminin Tanzimat'la birlikte ikiye bölünerek mektep-medrese ikiliğine ve rekabetine yol açması üzerine, toplum bu iki eğitim anlayışı etrafında gruplaşarak birbiriyle mücadeleye başlamış, neticede devlet desteği zayıflayan medrese kendi kabuğuna çekilmek suretiyle kendi kaderiyle baş başa kalmıştır ${ }^{60}$.

Medreselerin, kuruluş amacını teşkil eden İslâmî ilimlerin tahsili çerçevesinde eleştirilmesi, sorgulanması ve değerlendirilmesi gerekirken; Avrupa'daki muâdil eğitim kurumlarında olduğu gibi* -asrın şartları itibariyle- yardımcı dersler grubuna dâhil edilmiş olan aklî ilimlerin merkeze alınmak suretiyle eleştiriye tabi tutulması ve bu durumun gerilemenin ve bozulmanın ana gerekçesi olarak sunulması doğru bir yaklaşım olamaz. Kaldı ki medreseler Avrupa'daki üniversitelerle kuruluş amacı bakımından hiçbir benzerliği olmayan kurumlardır ${ }^{61}$. Nitekim, Sarıkaya'nın da belirttiği üzere: "Medreselerin gerilemesi ile aklî ilimler arasında bir bağ kurma, bu kurumların kuruluş amaç ve işleyişleri dikkate alındığında anlamsız -hatta imkansızkalmaktadır ${ }^{62}$." Sağlıklı bir değerlendirmenin yapılabilmesi, ancak medrese sistemini amaç, içerik ve işleyiş açısından bir bütün olarak anlamak ve değerlendirmekle mümkündür ${ }^{63}$. Kaldı ki Cevat İgi'nin Osmanlı Medreselerinde ilim isimli eserinde, tabiî ilimlerden; Tıp ilminin medrese programlarında daima yer aldığı, Fizik, Kimya, Botanik, Zooloji, Biyoloji, Mineraloji, Zirâat, Jeoloji ve Coğrafya gibi ilimlerin ise

60 Kodaman, a.g.e., s. XII, XIII.

* Adnan Adıvar, XVII. ve XVIII yüzyıllarda Fransa'daki resmi ve papaz mekteplerinin de tıpkı Osmanlı medreselerinde olduğu gibi eski skolastik usulden henüz ayrılamadığını ifade etmektedir. (Bkz. A.Adnan Adıvar, Osmanlı Türklerinde Illim, Remzi Kitabevi, 4.bs., İstanbul, 1982, s.177.)

${ }^{61}$ Recai Doğan, "Osmanlı Eğitim Kurumları ve Eğitimde Ilk Yenileşme Hareketlerinin Batılılaşma Açısından Tahlili", AÜif. Ilahiyat Fakültesi Dergisi, Ankara, 1997, C.37, S.1, s.420. (s.407-442)

62 Sarıkaya, a.g.m., s.30.

${ }^{63}$ Bkz. Sarıkaya, a.g.m., a.y.

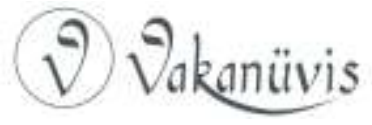


son devir Osmanlı medreselerinden Dârü'I-hilâfeti'l-aliyye Medresesi programına girinceye kadarki süreçte; medrese müntesiplerinin bütün bu ilim dallarında telif, tercüme, ihtisâr ve istinsah şeklinde tezâhür eden bir takım ilmî faaliyetler içinde bulundukları belirtilmektedir. Yine Aritmetik-Cebir, Geometri Astronomi ve Fizik gibi sürekli olarak Osmanlı medreselerinin müfredat programında yer alan derslerde yaygın olarak okutulan ders kitapları dışında, bunlar kadar yaygın okutulmasa da program dışı uzun ve yüksek seviyeli kitapların da meraklılarınca özel araştırma ve inceleme konusu yapıldığı belirtilmektedir ${ }^{64}$.

Diğer taraftan Ziya Gökalp(1876-1924) tarafından Dârü'l-íctihad olarak nitelendirilen medreselerin bu sıfatı hak etmelerine gerekçe gösterdiği merkez-i tahkik* özelliklerini kaybetmeleri ile çöküşün başladığı, dolayısıyla Osmanlı Devletinin iki asırdan beri uğradığı gerileme ve çöküş felaketinin sebeplerini, isabetli bir tesbitle medreselerin nitelik kaybına uğrayan tedrisatında aramak gerektiği anlaşılmaktadır ${ }^{65}$. Gökalp'in ortaya koymuş olduğu eleştirel değerlendirmelerin de, medresenin kurumsal yapısına yönelik olmayıp; medresenin tedrisatına yani uygulanan eğitim ve öğretimine ilişkin olduğu açıktır.

Netice itibariyle, "medrese sistemi, tarihi bağlam içerisinde düşünüldüğünde XVII. Asra kadar yeterli ve geçerli, ancak bu yüzyıldan sonra 'yenilenmeye' ve gelişmeye muhtaç bir sistemdi. Bir başka ifadeyle medresede 'bozulma' veya gerileme" değil, geleneği koruma uğruna yeniliklere ve değişime (yani çağa) 'intibak edememe' sorunu vardır"6. "Medrese bu durumu hiç fark edemediği gibi fark edenlere de fırsat vermedi. Ne kendini yenilemeye teşebbüs etti ne de kendi dışında bir yeniliğe, değişikliğe fırsat verdi" ${ }^{67}$. Bu dönemde medresenin temel sorununun zamanın şartlarına ve ihtiyaçlarına göre kendini yenileyememe sorunu olduğu apaçık ortadadır.

\footnotetext{
${ }^{64}$ Cevat İzgi, Osmanlı Medreselerinde Ilim, 2 c., İz Yay., İstanbul, 1997, c.1., s.26, 27.

* Türkçe ifadesiyle "araştırma merkezi" denilebilir.

65 Şevket Beysanoğlu, Ziya Gökalp’ın Ilk Yazı Hayatı(1894-1909), Diyarbakır'ı Tanıtma Derneği Neşriyatı, İstanbul, 1956, s.115,116.

${ }^{66}$ Sarıkaya, a.g.m., s.34.

67 Kodaman, a.g.e., s.XI.
}

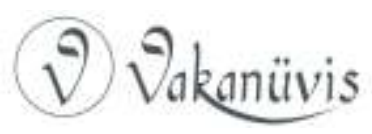




\section{Islahat Çabaları ve Sonuçları:}

İlmiye teşkilatının, büyük oranda devlet müesseselerinde başlayan genel bozulmadan etkilendiği aşikârdır ${ }^{68}$. XVI. yüzyılın ikinci yarsından itibaren illmiye sınıfında kendini göstermeye başlayan kanun ve nizam dışı uygulamaların yol açtığı olumsuzluklar, medreselerdeki tedrîsâtta seviye kaybına neden olmuş, gerek müderris ve ulemâ arasında gerekse talebe arasında liyâkat ve ehliyet sahibi olmayanların çoğalmasına kapı aralanmıştır. Devletin mâlî, idârî ve askerî teşkilatında gözlenen bozulmayla birlikte tedricen bozulmaya başlayan medreselerin de zaman zaman alınan bazı tedbirlerle ıslah edilmesine çalışılmıştır ${ }^{69}$.

Bu çerçevede, medreselerin ilk defa Islah edilmelerine duyulan ihtiyacın Sultan III. Mehmed(1566-1603)'in saltanatı döneminde (15951603 yılları arası) ortaya çıktığı belirtilmektedir ${ }^{70}$. III. Mehmet'ten önce Sultan III. Murad(1574-1595) tarafından 2 Şaban 985/15 Ekim 1577'de çıkartılan bir fermanda; Fatih Sultan Mehmed'in medreseler hakkındaki kanununun tamamen tatbiki emredilmiştir. Ancak bu hatt-ı humâyunun etkili olamadığı hususu; bozukluğun devam etmesinden ve giderek genişlemesinden anlaşılmaktadır ${ }^{71}$.

III. Mehmed'in emriyle mevâlîden* müteşekkil bir heyet tarafından ilmiye sınıfının ıslahına yönelik hazırlanan bir lâyiha, Hicri 1006 yılının Ramazan ayında (Miladi 1589 Nisan) Padişaha takdim edilmiş, mezkûr lâyihanın kanun olarak Kazaskerlere bildirilerek tatbiki emredilmiştir. Fatih Kânunnâmesi'nde yer alan hükümleri merkeze alan bir anlayışla medreselerin dereceleri ile müderris, mülâzım ve talebenin yükselme aşamalarına ilişkin kuralları detaylı bir şekilde ortaya koyan mezkûr Kânunnâme'nin, bir müddet sonra tatbikten kalkarak eski bozukluğun artarak devam ettiği görülmüştür ${ }^{72}$.

\footnotetext{
${ }^{68}$ Bkz. İpşirli, a.g.m., s.274.

${ }^{69}$ Bkz. Uzunçarşılı, a.g.e., s. 251.

70 Atay, Osmanlılarda Yüksek Din Eğitimi, s.175.

71 Bkz. Uzunçarşılı, a.g.e.,s.79, 251.

* Mevâli: Osmanlı devlet teşkilâtında mevleviyet pâyesine erişmiş üst seviyedeki ilim adamları, mollalar, büyük kadılar. (Kubbealtı Lügati, s.2069)

72 Bkz. Uzunçarşılı, a.g.e., s.253,256.
}

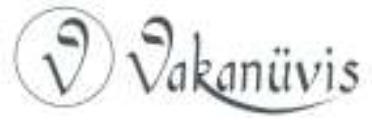


Yine Divan-ı Humâyun mühimme defterlerinde yer alan hükümlerden 28 Muharrem 987/27 Mart 1579 tarihli bir hükümde, tahsille iştigal etmeyen softaların gerçekleştirdikleri şekâvetleri önlemeye yönelik bir takım tedbir ve ıslahata yer verildiği belirtilmektedir ${ }^{73}$.

XVI. Yüzyılın ikinci yarısından itibaren Osmanlı devlet teşkilatında kendisini hissettirmeye başlayan bozulma ve çözülmeler nedeniyle bunu düzeltmeye yönelik olmak üzere çeşitli ıslahat lâyihaları kaleme alınmaya başlanmıştır. Bu lâyihalarda özellikle ilmiye teşkilâtında baş gösteren tertip ve düzen dışı uygulamalara da yer verilerek çözüm önerileri sunulmuştur. Nitekim birbirinin benzeri tesbit ve çözüm önerilerine yer verilen Gelibolulu Mustafa Âli'nin Nushatü's-Selâtîn ve Hazerfan Hüseyin Efendi'nin Telhîsü'l-Beyân isimli eserleri ile yazarı belirsiz olan Hırzü'l-Mülûk isimli eserde, ilmiye mesleğinde düzenin ve mansıp/terfi silsilesinin bozulduğu, mansıpların rüşvet ve iltimasla verilir olduğu tesbitlerine yer verilerek; mansıp tevcihinde liyâkat ve hak ölçütlerinin dikkate alınmasının gerektiği özellikle vurgulanmıştır ${ }^{74}$.

I. Ahmed devrinde (1603-1617), Hicri 1018 Recep/Milâdî 1609 Kasım tarihli adalet fermanında; menşei medrese olan ve adaleti temsil edecek olan kadılar hakkında olumsuz tesbitler ortaya konulduktan sonra bu başıbozuk gidişata son verilmesi yönünde kesin emir verilmiş, ancak ilmiye teşkilatındaki bozulmanın önüne geçilememiştir ${ }^{75}$.

Medreselerin ıslahı hakkında zaman zaman fermanlar tamim edilmiş ise de iltimâs ve himâye yüzünden bu emirler tatbik edilmeyerek yolsuzluk devam etmiştir. Bu sınıfın ıslahı hakkında III. Ahmed zamanında da (XVIII. Asrın ilk yarısı-1703-1730) bazı emirler verilmiş ise de bu hususta I. Mahmud devrinde ıslah işi daha ciddi tutulmuştur ${ }^{76}$.

I. Mahmud (1730-1754)'un, Şeyhülislâm Murtezâ Efendi'ye göndermiş olduğu 1163/1750 tarihli Hatt-ı Hümâyun'da, mülâzemet

\footnotetext{
73 Bkz. A.e., s. 252-253.

${ }^{74}$ Bkz. Mehmet Öz, Kanun-i Kadimin Peşinde-Osmanlı'da Çözülme ve Gelenekçi Yorumcuları, Dergâh Yayınları, 6.bs., İstanbul, 2009, s.60-102.

${ }^{75}$ Bkz. Uzunçarşılı, a.g.e.,s.259-261.

${ }^{76}$ A.e., s. 263.
} 
ve müderrislik yolunun bozularak; iltimas ve himaye ile ehliyetsiz kimselerin müderris oldukları ve ilim yolunun bu gibilerden temizlenerek, medreselere ehlinin tâyin edilmesi emredilmiş ${ }^{77}$, ancak bu düzenleme ile de bir yenilik getirilememiş; ne ders ne de tedris süresi gibi konulara temas edilmediğinden, sadece eski kanun ve tüzüklerin uygulanması istenmiştir ${ }^{78}$.

Pek çok ferman ve kanunlara rağmen düzelmeyen medreseler ve ilmiye sınıfına ilişkin olarak III. Selim(1761-1808) tarafından da ıslahat girişiminde bulunulmuştur ${ }^{79}$. 1789-1808 yılları arasında sürdürdüğü saltanatının ilk günlerinde bazı devlet ricalini toplayarak, daha önce kaleme aldırdığı ıslahat lâyihasını okutturan III. Selim, mecliste hazır olanların mütalaalarını sormuş, yapılan müzakerelerin ardından Şeyhülislam Mehmed Kamil Efendi'ye, yapılacak ıslahatı bir karara bağlamalarını emretmiştir. Bu dönemde ilmiye ıslahatında başarı elde etmek isteyen III. Selim'in Şeyhülislamlığa getirdiği Hamidizâde Mustafa Efendi köklü bir ıslahata girişmiş, ardından Şeyhülislamlık makamına getirilen Dürrizâde Mehmed Arif Efendi tarafından ilmiye ıslahatı hakkında padişaha takdim edilen bir arîza Hicri 1207 yılı Şaban ayında(m.1793 yılı Nisan ayı) kabul edilerek bir Hatt-ı Humâyunla Şeyhülislam'a iade edilerek uygulanması emredilmiştir ${ }^{80}$. Bahse konu düzenlemede imtihansız mülâzemet verilmemesi ve imtihansız kadı tayin edilmemesi hususlarının yer alması; getirilen düzenlemenin ilmiye boyutuna ilişkin kısmını ortaya koymaktadır ${ }^{81}$. Nitekim kadılara mahreç teşkil eden kurum olarak medrese gerek ilmiyeye gerekse adliyeye beşeri kaynak/çıktı sağlamaktadır. Sistem yaklaşımı çerçevesinde ele alındığında bir işletmenin ürettiği çıktı/ürün kalitesi, kontrol/denetim ya da eğitimsel ifadesiyle sınavlar ile mümkün olabilmektedir.

Tanzimat Dönemine gelindiğinde; kamu eğitimi ve maarifin devletin işi olduğu yönündeki -o çağ için yeni olan- fikir benimsenmiş ve bu

\footnotetext{
${ }^{77}$ A.y.

${ }^{78}$ Atay, Osmanlılarda Yüksek Din Eğitimi, s.184.

79 Bkz. Enver Ziya Karal, Selim III'ün Hat-tı Hümayunları-Nizam-ı Cedit-(1789-1807), TTK. Yay. 2.bs., Ankara, 1988, s.123-131.

80 Bkz. Uzunçarşılı, a.g.e., s.264-265.

${ }^{81}$ Bkz. a.e., s.266.
}

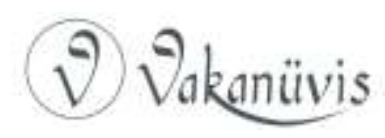


dönemin kurumsal modernleşme siyasetinin önemli araçlarından biri olarak devlet okullarının açılmasına başlanılmıştı ${ }^{82}$. Tanzimatçılar masrafları devletin üstlendiği ama laikleştirilmiş bir sivil eğitim tasarlamışlardı; mevcut mektep ve medreseleri modern eğitim ocakları haline getirmek söz konusu değildi onlar açısından. Bu nedenle Tanzimat döneminden itibaren; biri din temelli ve geleneksel, diğeri daha o zamandan daha laik nitelikli ve modern iki farklı okul ağı bir arada var olmaya başladı ${ }^{83}$. Ancak batı tarzındaki mekteplerin yoğun bir şekilde açılmaya başlanması ve özellikle 1867 yılından itibaren Sultânî mekteplerin açılması ile birlikte geleneksel medrese zemin kaybına uğramışı ${ }^{84}$. Bu durumun farkına varan ilmiye mensuplarından oluşan 15 kişilik bir heyet, Milâdî 1867 (1284 h.) yılında bir rapor hazırlamak suretiyle yetkili makama sunmuştur ${ }^{85}$. Bu rapor, eğitimöğretimin yeniden yapılandırılmasına olan ihtiyacı ortaya koyması açısından önemlidir.

Islahata duyulan ihtiyacın gerekçelerine ilişkin açıklamaları içeren bir girizgâhın yer aldığı mezkûr raporda: önceki devirlerde ilme verilen öneme ve ulaşılmış olan ilmî düzeye atıf yapılmış, ancak bir müddetten beri şerh ve haşiyelerin ilavesiyle birlikte derslerde yapılan müzakerelerin kat edilecek mesafeyi uzattığı ve eğitim-öğretime yeni başlamış çoğu talebenin zihninin dedikodu tarzındaki bilgilerin ağırlığı altında ezilerek; yorum yapma ve hüküm çıkarma yeteneklerine dayanak olacak usûl ve kâidelerden mahrum kaldıkları, bu nedenle talebenin, medrese eğitimi için belirlenmiş olan hedefe ulaşmadıkları vurgulanmıştır. Çözüm olarak şerh ve haşiyelerin programdan çıkartılması önerisi getirilerek, eğitimin gerçek anlamda ıslahı ve programın geliştirilmesine ilişkin karar ve teklifler sıralanmıştır. Bu kararlar arasında başta Arapçanın öğretimi ile ilgili olarak Emsile, Binâ, Maksûd, Avâmil, izhâr ve Kâfiye olmak üzere isagoji, Fenârî, Tasavvurât, Tasdîkât, Şerh-u Akâid, Kadimir ve Celâl isimli kitaplar ile ayrıca ikindi derslerinde ve tatil günlerinde okutulacak olan kitapların işleniş yöntemlerine ilişkin açıklamalara yer verilmiştir. İlaveten

\footnotetext{
82 Bkz. François Georgeon, Sultan Abdülhamid, çev. Ali Berktay, Homer Kitabevi, İstanbul,2006, s.290.

83 Georgeon, a.y.

${ }^{84}$ Bkz. Atay, "Medreselerin Islâhı", Aüif. Dergisi, Ankara,1982, c.25, s.14.

${ }^{85}$ Beyânü'l-Hak, S.15, s.322-324.
} 
derslerde gerçekleştirilecek olan müzakerelerin ne suretle yapılacağına dair ayrı bir bölüm açılmak suretiyle yöntem konusuna ilişkin örnek uygulama üzerinden açıklamalar yapılmıştır ${ }^{86}$. Bahse konu raporda yer alan tesbitlerin doğru ve isabetli tesbitler olduğu görülmesine karşın, önerilen ders programının Fatih zamanındaki ders programından daha geri ve daha düşük bir ilmî seviyede olduğu hususu Atay tarafından dile getirilmektedir $^{87}$. Dolayısıyla mezkûr programın da medreselere yeni ve daha gelişmiş bir düzenleme getirmediği anlaşılmaktadır.

Öte yandan, Osmanlı Devlet'inin değişik kademelerinde görev yapmış olan ve ayrıca Maarif Nazırlığı ve Sadrazamlık görevi de ifâ etmiş olan Mehmed Esad Safvet Paşa(1814-1883)'nın II. Abdülhamid'e sunmuş olduğu 10 Muharrem 1297/3 Ocak 1880 tarihli ârizasında, medreselerin ıslahına ilişkin önemli tesbit ve önerilere yer verildiği görülmektedir. Medreselerdeki ders programının 200 yıl önce benimsenmiş bir program olduğu; eğitim usulünün de yine belirlenmiş kalıbın dışına çıkmayan bir usûlde devam ettiği tesbitine yer veren Safvet Paşa, bu program ve usûlle, arzulanan verimin elde edilemeyeceğini; verdiği örnekler üzerinden açıklamaktadır. Safvet Paşa, çözüm olarak müfredâtın ve öğretim yöntemlerinin günün şartlarına uygun bir şekilde yenilenmesini, aklî ve fennî ilimlerin ders programına dahil edilerek okutulmasını, bazı derslerin tebdiliyle birlikte bazılarının da kısaltılmasını önermektedir. Ayrıca teklifler arasında yer alan, medreselerin bulundukları mevkilere göre büyük camiiler etrafında toplanarak*, bu camilerin eğitim amaçlı kullanılması teklifinin $^{88}$; eğitimin sevk ve idaresinin daha planlı, daha etkin ve uygulamalı bir şekilde gerçekleştirilmesi amacına yönelik olduğu düşünülmektedir.

Medreselerin içine düşmüş bulunduğu olumsuzlukların düzeltilmesi amacıyla gerek devleti yönetenler tarafından gerekse bireysel olarak ulemâ tarafından gerçekleştirilen pek çok girişimlerden biri de 1897

\footnotetext{
${ }^{86}$ Beyânül-Hâk, a.y.

${ }^{87}$ Bkz. Atay, Medreselerin Islâhı, s.19.

* Bu öneri, 1909 yılında Peymân isimli gazetede yayınlanan ve Ziya Gökalp'e ait olduğu belirtilen "Medreseler" isimli makaledeki, medreseler için önerilen "Külliye" tarzı yapılanma fikrini çağrıştırmaktadır.

${ }^{88}$ Atila Çetin, "Medreselerin Islahına Dâir Safvet Paşa'nın Düşünceleri ve Bir Arizası", Türk Dünyası Dergisi, Kasım-1994, No:95, s.16-18.
}

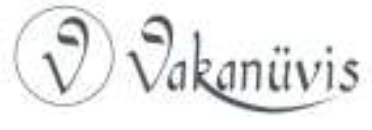


yılında Şeyh Ali Efendizâde Muhyiddin tarafından hazırlanan programdır. Bilindiği kadarıyla medreselere yeni müsbet ilimlerin konmasını ilk defa bu zât müdafaa etmiş ve medreselerin geri bırakılmasının sebeplerini açıklamıştır ${ }^{89}$.

Farklı din ve etnik grupları içinde barındıran İmparatorluğun, köklü ve tek örgün eğitim kurumu olan medreselerin tüm tebâya hizmet veren bir kurum haline dönüştürülmesi elbette ki imkânsız bir durumdur. Medreseler her ne kadar devletin kontrol ve denetiminde olsalar bile vakıflar eliyle faaliyet yürüten özel eğitim kurumları niteliğini taşımaktadır. Bu nedenle, Tanzimat'la birlikte açılmaya ve yaygınlaşmaya başlayan yabancı ve azınlık okullarına alternatif olacak ve onlarla rekabet edecek batı tarzı eğitim kurumları tesis etme zorunluluğu ile karşı karşıya kalındığı bir dönemde; bu görevi, verilen eğitimin niteliği itibariyle tek başına medreselerin üstlenmesi düşünülemezdi. Tanzimat'la başlayıp II. Meşrutiyet'in ilanına kadar geçen süreçte ve özellikle II. Abdülhamit döneminde; gerek sayı itibariyle gerekse çeşitlilik itibarıla yoğun bir şekilde mekteplerin açılmasına karşın medreselerde nicelik ve nitelik itibarıyla herhangi bir gelişmenin gözlenmemiş olması medreselere olan ilgi ve alakanın azalmasına yol açmıştır. Öte yandan, Tanzimat'la birlikte mektepleşme yoluna girilmesinde önemli katkı sağlayan ve fiilen görev alanların başında ilmiye mensuplarının gelmesi ${ }^{90}$, mekteplerin öğretmen ve öğrenci ihtiyacının büyük ölçüde medreselerden karşılanması ve ayrıca devlet kurumlarının işlemesinde ve idâri çarkın dönmesinde medrese çıkışlıların önemli katkılar sağlamış olması ${ }^{91}$; kendi kaderiyle baş başa bırakılmış olan medresenin bu haliyle bile önemini ve eğitim düzeyini ortaya koyan önemli göstergelerdendir. Bahse konu süreçte ulemânın azımsanmaması gereken rolü ve icraatı söz konusudur ${ }^{92}$. Nitekim, eğitimdeki modernleşmenin sembolü olan mekteplerin açılış sürecinde

\footnotetext{
89 Bkz. Atay, a.g.m.,s.39.

90 Bkz. Georgeon, a.g.e., s.348; Sarıkaya, Medreseler ve Modernleşme, s.58,59.

91 Mustafa Ergün, II. Meşrutiyet Devrinde Eğitim Hareketleri-(1908-1914), Ocak Yay., Ankara, 1996. s.326.

92 Mahmut Dilbaz, Askeri Modernleşmenin Dinî Müdafaası-Es'ad Efendinin Şerhli EsSa'yü'l-Mahmûd Tercümesi , Dergah Yay., İstanbul, 2014, s.9.
}

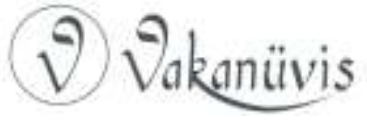


oluşturulan kurullarda medrese ve ulemânın görev alması dikkat çeken önemli bir bilgidir ${ }^{93}$.

$\mathrm{Bu}$ dönemde mekteplere olan rağbet ve yöneliş, tamamen konjonktürle alakalı bir durumdur. İşin doğası gereği yeni tarzda eğitim veren kurumların açılmış olmasının; geleneksel eğitim kurumlarının gözden ırak kalarak yerinde saymasına, hatta gerilemesine yol açtığı söylenebilir. Ancak Tanzimat'la birlikte başlatılan yenileşme hareketlerinin mektepleri merkeze alan bir yaklaşıma sahip olması nedeniyle; geleneksel eğitim kurumu olan medreselerin hayatın dışına itilme süreciyle karşı karşıya kaldıkları inkâr edilemez bir gerçektir ${ }^{94}$. Nitekim 1869'da yayımlanan Maârif-i Umûmiye Nizamnâmesi ile eğitimde tamamen Batı örneği bir sisteme geçilmesi ${ }^{95}$ medreselerin yüzüstü bırakııısının resmî ve somut adımıdır.

Öte yandan, Yeniçeri Ocă̆ı'nın 1826 yılında kaldırılışına kadar ilmiye sınıfıyla ittifak kuran ve genel olarak ulemânın desteğini alan siyasi irade, Yeniçeriliğin kaldırımasından sonra kendisine rakip gördüğü tek dengeleyici büyük güç olan ilmiye sınıfıyla ittifakını sona erdirerek, ilmiyenin statü ve itibar kaybına yol açacak bir tavır benimsemiştir. Bu tavır özellikle eğitim alanında gerçekleştirilecek olan reformların ilmiye sınıfıyla yürümeyeceği öngörüsünden kaynaklanmaktadır ${ }^{96}$.

Osmanlı Devleti'nin modernleşme dönemindeki temel hedefinin; askeri ve teknolojik alanlarda modernleşerek savaşlarda yenilmemek, bürokrasiyi modernleştirerek çevreye daha etkin şekilde nüfuz edebilmek olduğu bilinmektedir. Bu çerçevede gerek Tanzimat döneminde ve gerekse II. Abdülhamid'in saltanatı yıllarında, açılmış olan mektepler ideolojik aygıt olarak da değerlendirilmiş ve bu mektepler aracılı̆̆ıla merkezin çevreye nüfuz gücünü geliştirmeye ve

93 Alkan, a.g.e., s.3; ayr. bkz. Uğur Ünal, Togay S. Birbudak, Istanbul Dârülmuallimîni(1848-1924), Atatürk Kültür, Dil ve Tarih Yüksek Kurumu, Ankara, 2013, s.10.

${ }^{94}$ Bkz. Kemal Bakır, "II. Meşrutiyet Döneminde Milli Seçkincilik ve Eğitim: Emrullah Efendi Tûba Ağacı Nazariyesi", Doğu Batı-Düşünce Dergisi, Yıl:11, No:45, Temmuz, 2008, s.201.

95 Mustafa Ergün, "Batılılaşma Dönemi Osmanlı Eğitim Sistemine Mukayeseli Bir Bakış", s.91.

96 A.y.

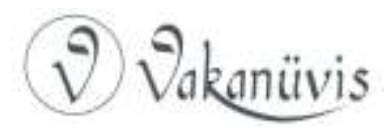


bürokrasi, askeriye gibi merkezin gücünü sağlayan kurumlara eleman yetiştirilmeye çalışılmıştır ${ }^{97}$. Ayrıca mektepler halkın padişaha, Osmanlı hanedanına ve hilafet kurumuna bağlılığını güçlendirmenin bir aracı olarak görülmüştür ${ }^{98}$.

Tanzimat'tan II. Meşrutiyet'in ilanına kadar geçen süreçte Osmanlı yöneticilerinin ve özellikle de II. Abdülhamid'in maarif siyaseti, gayrimüslimlere ait okulların gelişimini dengeleme kaygısıyla; hem rekabet ruhu hem de savunma refleksiyle cevap vermekten ibarettir ${ }^{99}$. Bu dönemde medrese karşıtı bir siyasetten bahsetmek yerine batı tarzı mekteplere duyulan ihtiyacın getirdiği; faydacı yaklaşımının hakimiyetinden bahsedilebilir. Devlet okulları olarak açılan mekteplere, modern konularda yetkin ve aynı zamanda devletine ve sultanhalifesine bağlı, iyi idareciler yetiştirme görevinin verilmiş olması, ayrıca müfredattaki din ve ahlak ders saatlerinin birkaç kez artırılması ${ }^{100}$ medreselerin ıslahına nisbetle daha pratik ve ulemânın gücünü dengeleyen makul bir yaklaşım olarak görülmekteydi. Ayrıca her geçen gün, sayısı artarak yaygınlaşan mekteplerin ders programlarında dînî derslerin payının artırılması suretiyle devletin resmi din anlayışının daha hızlı bir şekilde benimsenmesi ve yaygınlaşmasını sağlama fırsatı yakalanmış, diğer taraftan medrese ve ulemânın gücünün zayıflatılması amaçlanmıştır. Özel vakıflar eliyle faaliyet yürüten ve denetimi güç olan medreselerin elindeki 'dînî bilginin ve din algısının yeniden üretilmesi' fonksiyonunun, modern mekteplerin ders programına konulmuş olan dinî içerikli derslerle işlevsiz kılınması, devletin resmi ideolojisinin tabana ulaşmasında ve yaygınlaştırılmasında en pratik yol olarak değerlendirilmiştir ${ }^{101}$.

Öte yandan II. Meşrutiyetin ilanıyla birlikte medreselerde ihtiyaç duyulan ıslahata ilişkin fikirlerin tartışılmasında ve basın yayın

\footnotetext{
97 Caner Taslaman, Küreselleşme Sürecinde Türkiye'de İslam, İstanbul Yay., 8.bs., İstanbul, 2014, s.52.

98 François Georgeon, Sultan Abdülhamid, çev. Ali Berktay, Homer Kitabevi, İstanbul, 2006, s.292.

${ }^{99}$ Georgeon, a.y.

100 Georgeon, a.y.

101 Bkz. Mehmet Ö. Alkan, "Osmanlı İmparatorluğunda Modernleşme ve Eğitim", Türkiye Araştırmaları literatür Dergisi(Türk Eğitim Tarihi),BiSAV yay.,c.6, S.12, İstanbul, 2008, s.13-16.
}

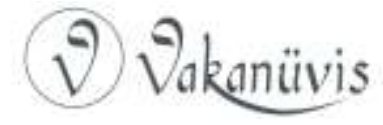


organlarında yer bulmasında artış yaşanmıştır ${ }^{102}$. Nitekim 1 Ramazan 1327/16 Eylül 1909 tarihli Sırâtımüstakim'de Tunalı Hilmi tarafından kaleme alınan "Medreseler Kongresi ${ }^{103}$ " başlıklı makalenin alt başlığının Osmanlı Müslüman Ulemâsına Bir Davet adını taşıması, medreselerin içinde bulunduğu sorunların çözümü için çeşitli platformlarda çıkış yolları arandığının mühim bir göstergesidir. Yazar, medreselerde ıslahata duyulan ihtiyacın acil çözümü amacıyla konuyla ilgili istişârelerin ve tüm sancak ve vilayetlerde yapılacak olan kongrelerin akabinde her yıl düzenlenecek olan 'Osmanlı Medreseleri Kongresi'nin tertip edilmesi teklifini getirmektedir. Makalede medreselerin selâmeti; ıslahına bağlanmakta, esaslı eleştirilerle birlikte askerî alanda nasıl yenilikler gerçekleştirilmişse; medreselerde de aynı yenileşmenin gerekliliği vurgulanmaktadır.

Bu dönemde Ders Vekâleti tarafından alınan kararlarda medreselerde ıslahatın gerekliliğine ilişkin pek çok kararla birlikte medreselerin mevcut durumunu tüm teferruatıla ortaya koyan açıklamalara yer verilmiştir. Diğer taraftan İttihat ve Terakki Fırkası ileri gelenlerinin değişik mahfillerde gerçekleştirdikleri toplantılarda medreselerin ıslahına duyulan ihtiyaca ilişkin fikirlerini ortaya koyarak bir eğitim politikası belirlemeye çalıştıkları da görülmektedir ${ }^{104}$.

II. Meşrutiyet'in ilanıyla birlikte öteden beri medreselerde ihtiyaç duyulan ıslahatın gerçekleştirilmesine müsait ortam bulunması üzerine, ıslahatın ilk ve önemli bir adımı olarak 30 Kanunusâni 1325/12 Şubat 1910 tarihinde Fatih Tabhâne Medresesi'nde başta Sadrazam Hakkı Paşa olmak üzere Şeyhülislam Hüseyin Hüsnü Efendi, Heyet-i Vükelâ üyeleri, Maarif Nazırı Emrullah Efendi, Meclis-i Âyan Reisi Said Paşa, Meclis-i Mebusân Reis-i Sânisi Mustafa Asım Efendi, Meclis-i Âyan ve Mebusân üyeleri ile ulemânın ve halkın ileri gelenlerinden pek çok zevâtın iştirak ettiği resmî bir merasim tertip edilmiştir. Bu merasim ile "bilumum medâris-i ilmiyyede ve islâmiyye'de tatbik edilmek üzere tanzim edilen cedvel-i durûs ve ez-an cümle ulûm-ı

102 Bkz. Atay, Osmanlılarda Yüksek Din Eğitimi, s.214-225. (Özellikle medreselilerin kaleminden dönemin basınına yansıyan, medreseye yönelik eleştirilere detaylı bir şekilde yer verilmiştir.)

103 Tunalı Hilmi, "Medreseler Kongresi”, Sırâtımüstakîm, S.54, c.3, s.25-28.

104 O. Nuri Ergin, Türkiye Maarif Tarihi, Eser Matbaası, İstanbul, 1997, c.1, s.118.

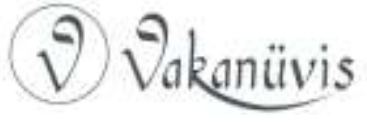


riyâziyyenin ta'lîm ve tedrîsine bed'-ü mübâşeret edileceği" ilan edilmiştir ${ }^{105}$. Ders Vekili Halis Efendi'nin mezkur merasimde yapmış olduğu konuşmada vurgulamış olduğu üzere: "Medâris-i islamiyye'nin usûl-i tedrisini ıslah ile beraber fünûn-ı hâzıraya ait dersler müfredâta dahil edilmiş ${ }^{106 " ~ b u ~ k a p s a m d a ~ f u ̈ n u ̂ n ~ d e r s l e r i n ~ e g ̆ i t i m i n i n ~ v e r i l e c e g ̆ i ~}$ müstakil dershaneler açılmaya başlanmıştır.

14 Şubat 1325/27 Şubat 1910 tarihli Medâris-i ilmiye Nizamnâmesi ${ }^{107}$, II. Meşrutiyet döneminde medreselerde gerçekleştirilmek istenen düzenlemelerin ilk somut örneğini teşkil etmektedir. 48 maddeden müteşekkil olan mezkûr nizamnâme, medreseleri yeni ve sistematik bir yapıya dönüştürmeyi amaçlıyordu. Medresenin yönetimi ile eğitim-öğretim ve diğer konularda pek çok düzenlemenin yer almış olduğu nizamnâme; klasik medrese yapısının dışına çıkılarak mekteplerdeki yapılanmaya benzer bir düzenleme getirmektedir. Özellikle imtihanlar ve sınıf geçme sistemi ile birlikte fünûn/fen ilimleriyle alakalı derslerin programa dâhil edilerek; bu derslerin okutulacağı yeni dershanelerin açılmasının planlanmış olması dikkat çeken yeniliklerdendir. Medresenin yönetimine ilişkin hükümlere yer verilmiş olan birinci bölümde, medresenin düzene sokulmasına ilaveten personel ve öğrencilerin devam ve devamsızlığının kontrol altına alınması amaçlanmaktadır. Bu nizamnâme ile getirilen en önemli yenilik ise 30'uncu maddede şu şekilde izâh edilmektedir: "Medârisde öteden beri tedris olunmakta bulunan derslere zam ve ilavesi lâzım gelen fünûn ile; terk ve tebdîli iktizâ eden şurûh ve havâşînin yerlerine ahsâr ve enfa' olan âsârın vaz' ve kabulü ve ilâve olunan fünûnun tahminen beş sene zarfında ale'ttedrîc rahle-i tedrîs ve tâlime vaz'ı mukarrerdir. ${ }^{108 " ~}$

Böylece fünûn/fen ilimleri kapsamındaki derslerin medrese müfredatına dahil edilmesine; daha önce ders kitabı olarak okutulan şerh ve hâşiye kitaplarından değiştirilmesi gereken kitapların yerlerine daha kısa ve daha faydalı olan eserlerin kabul edilmesine, ayrıca

\footnotetext{
105 Sırâtımüstakîm, S.76, c.3, s.379; Beyânü'l-Hâk, c.2., S.47, s.11.

106 Sırâtımüstakîm, S.76, c.3, s.381.

107 Düstur, Tertib-i Sânî, C:2, Matbaa-ı Osmaniye, Dersaâdet, 1330, s.127-138.

108 A.g.e., s.133.
}

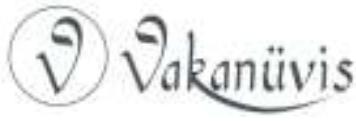


müfredata ilave edilen fünûn derslerin beş yıl içerisinde tedricen programa dahil edilerek okutulmasına karar verildiği görülmektedir.

Fünûn-i cedîde diye tabir edilen fen ve matematik ilimlerine medrese programında yer verilmeye başlanılması, medresede gerçekleştirilmeye çalışılan düzenlemelerin önemli bir boyutunu oluşturmaktadır. Bu düzenlemenin pek çok fiziki yapı ve donanım eksiklikleriyle beraber, yeni intibak sorunlarını da ortaya çıkardığı bir gerçektir ${ }^{109}$. Öte yandan, 21 Kânûnusânî 1329/3 Şubat 1914 tarihli bir yazıda İstanbul'da mevcut 28 dershanenin fünûn-i munzamme* derslerinin eğitim-öğretimine tahsis edildiği, ancak bu dershanelerin ihtiyacı karşılamaması nedeniyle yenilerinin açılmasına ilişkin planlamaların yapıldığının belirtilmesi; bu derslere olan rağbetin göstergesidir ${ }^{110}$.

Netice itibariyle, medreselerin varlığını koruduğu bütün dönemler boyunca en önemli değişikliklerin gerçekleşmiş olduğu II. Meşrutiyetin ${ }^{111}$ ilânıyla birlikte, ders programında fünûn derslere de yer verilmesi teşebbüsünde bulunulmuş, ancak bir takım olumsuzluklar nedeniyle arzulanan hedefe ulaşılamamıştır. Bu değişikliklerin gerçekleşmesi için Mustafa Hayri Efendi'nin şeyhülislamlık görevine gelişine kadar beklemek zorunda kalınmıştır. Nitekim Medâris Umum Müfettişi Abdullah Efendi tarafından Ders Vekâleti Aliyyesi'ne hitaben yazıımış olan 17 Kânûnuevvel 1328/30 Aralık 1912 tarihli bir yazıda ${ }^{112}$; fünûn derslerin eğitimi için uygun bir dershane tesbit etmek üzere gerçekleştirilen teftiş sonucunda elverişli bir dershane bulunamadığı, ancak Fatih Camii avlusundaki Bahr-i Siyah Tetimme-i Sâdise ve Sabiâ medreselerinin yeniden inşa edilmekte olması nedeniyle, bu medreselere ait çamaşırhanelerin üzerinin dershane yapılmasına müsait olduğu; dolayısıyla bahse konu yerlere birer dershane ilave

${ }^{109}$ Bkz. İstanbul Müftülüğü Meşihat Arşivi(iMMA), Meclis-i Mesâlih-i Talebeye Mahsus Müsvedde Varakaları (MMTMMV), nr.2061, s.43,44; IMMA, MMTMMV, nr.2064, s.153.

* Fünûn-i Munzamme: Medrese derslerine ilave edilen fen dersleri.

110 iMMA, MMTMMV, nr.2064, s.153.

${ }^{111}$ Nesimi Yazıcı, "Osmanlıların Son Döneminde Din Görevlisi Yetiştirme Çabaları üzerine Bazı Gözlemler", Diyanet Dergisi, S.4, C.27, Ankara, 1991, s.65.

112 IMMA, MMTMMV, nr. 2060, s.102.

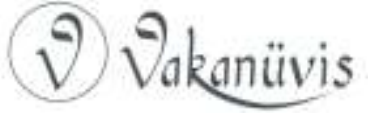


edilerek fünûn dersler için tahsis edilmesinin uygun olacağı yönünde kanaat belirtildiği görülmektedir.

Diğer taraftan II. Meşrutiyet döneminde medreselerin iyileştirilmesine ilişkin ilk düzenleme olan Medâris-i ilmiye Nizamnâmesi'nin, medresenin idari yapısına ilişkin esaslı maddeler içermediği görülmekle beraber, kayıt-kabul işlerinin düzene sokulması; müderrislerin, dersiâmların ve bevvapların görevlerinin belirlenmesi; talebenin uyacağı kuralların açıklanması; basit de olsa giriş imtihanının ihdas edilmesi; uzun haşiye ve şerhler yerine kısa ve faydalı eserlerin ders kitabı olarak okutulması, başta Türkçe olmak üzere Edebiyat, Riyaziyât, Fârisi, Hendese, Coğrafya, Tarih, Hikmet, Cebir, Hendese, Kimya, Mevâlid, Kozmografya derslerinin programa dâhil edilmesi; fünûn-u cedîdenin okutulacağı dershanelerin oluşturulması ve eğitimöğretim yılı sonunda sınıf geçme imtihanlarının yapılması gibi ilk defa uygulamaya konulacak önemli düzenlemeleri ihtiva ettiği, ancak ilmî alandaki bu dönüşümü ve inkılabı iyi bir şekilde yönetecek idâri teşkilata gereken önem verilmediği için sonuç alınamadığı yönünde değerlendirmeler yapılmaktadır ${ }^{113}$.

Meşihat Makamına hitaben Meclis-i Mesâlih-i Talebe ${ }^{114}$ tarafından hazırlanmış olan 19 Şubat 1914 tarihli bir yazıda da, medreselerin mevcut durumuna ilişkin önemli tesbit ve değerlendirmelere yer verildiği görülmektedir ${ }^{115}$. Önemli öz eleştiriler içeren yazının devamında Sebilürreşâd gazetesinin 14 Rebiülâhir 1332-12 Mart 1914 tarihli nüshasında yayımlanmış olan Medresetü'l-Mütehassısîn Nizamnâmesi ${ }^{116}$ yer almaktadır. Bahse konu yazı medreseye ilişkin serdedilmiş olan tüm tenkit ve tekliflerin rafine edilmiş bir özeti olması hasebiyle; dönemin medreselere bakış açısını ve medreselerde ıslahata duyulan ihtiyacı ortaya koyması bakımından önemlidir.

\footnotetext{
113 Müftüzâde, "İstanbul Medreseleri-II", Sebilürreşâd, S.542-543, c.21, s.176.

114 Meclis-i Mesâlih-i Talebe hakkında detaylı bilgi için bkz. Hasan Yıldız, "Osmanlı Medrese Eğitim Sisteminde Karar Organı: Meclis-i Mesâlih-i Talebe Ve Müfredât Programlarını Hazırlama Sürecindeki Rolü (II. Meşrutiyet Dönemi Örneği)", İstanbul Üniversitesi Türkiyat Mecmuası, 2018, c.28, S.2, s.255-275.

115 iMMA, Meclis-i Mesâlih-i Talebe Defteri (MMTD), nr.2203, s.3-5.

${ }^{116}$ Sebilürreşâd, S.287, c.12, s.11,12.
}

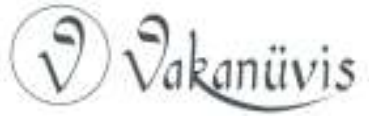


Mezkûr yazı, II. Meşrutiyet döneminde Maarif Nazırlığı yapmış olan ve Osmanlı Eğitim Teşkilatının şekillenmesinde önemli görevler üstlenmiş olan devlet adamı ve eğitimci Emrullah Efendi'nin Tûbâ Ağacı Nazariyesi'nin* medreselerde uygulanmasının gerektiği iddiasından yola çıkılarak hazırlanmış ve bu konuda ikna edici delillere ve yorumlara yer verilmiştir. Osmanlı medreselerinin tarihsel sürecine ilişkin yapılan genel değerlendirmenin ardından bahse konu nazariye gereğince: medreselerde önce en üst düzeydeki eğitim biriminin ayağa kaldırılması, buradan nitelikli ve donanımlı müderrisler yetiştikten sonra ise alt kademedeki kısımların eğitiminin ele alınması gerektiği ortaya konulmuş; bu çerçevede Medresetü'l-Mütehassısîn Nizamnâmesi hazırlanarak işe başlanılmıştır. Maârif Nâzırı Emrullah Efendi'nin İttihat ve Terakkî Fırkası'nın önemli isimlerinden birisi olması hasebiyle onun geliştirmiş olduğu Tûbâ Ağacı Nazariyesi'nin medreselerde planlanan ıslahatta etkili olduğu anlaşılmaktadır.

Mezkûr Nizamnâme'nin ve bahse konu nazariyenin medreselerde uygulanmasına ve sonuçlarına ilişkin değerlendirmeler ayrı bir araştırma konusu niteliğindedir. 1914 yılı itibariyle medreselerin ıslahına ilişkin olarak İlmiye sınıfının yaklaşımını göstermesi açısından Meclis-i Mesâlih-i Talebe'nin mezkûr yazısını meâlen alıntılamakta fayda mülahaza ediyoruz.

“...asırlardan beri ümmetin ileri gelenlerini yetiştirmiş olan Medârisi İslâmiyyemiz yavaş yavaş eski ihtişam ve gücünü kaybederek, peş peşe gelen asırlarda inhitâta/gerilemeye yüz tutmuştur. Medreselerde mevcut olan şu inhitât ve inkırâzın (gerileme ve çöküşün) başlıca sebepleri medreselerin her asrın intiyacına göre tadil ve ıslahı ihmal edilerek, "zamanın değişmesiyle hükümlerin de değişeceği "hükmünü dünyaya telkin eden ilmiyye mensuplarının, her nasılsa medâris-i İslâmiyye hakkında bu hükümden gafil olmaları; medreselerdeki eğitimöğretim işinin yenileşmesine ve gelişmesine büyük bir engel teşkil ettiği gibi, Sultan Fatih zamanında kurulan teşkilat ve eğitim usulüne bile riayet olunmamakla beraber, yine o asırda önemi ve gerekliliği takdir edilip medreselerde öğretilen ilimlerin ve faydalı kitapların

\footnotetext{
* Tûbâ Ağacı Nazariyesi; Emrullah Efendi'nin "Maarif Tûbâ Ağacına benzer" ilkesinden hareketle eğitimde düzeltme işine yüksek öğretimden başlanılması şeklinde formüle ettiği tezi ifade etmektedir. (Bkz. Hasan Ali Koçer, Türkiye'de Modern Eğitimin Doğuşu (1773-1923), Uzman Yay., Ankara, 1987, s.171.
}

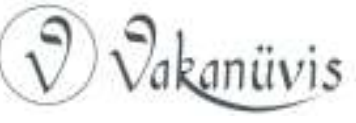


programdan çıkartılarak yerine hiç de faydası olmayan ve sadece kelime türetmekten başka bir işe yaramayan şerhlerin ve hâşiyelerin kabul edilip, Cebir, Riyâzîyat ve benzeri faydalı ilimlerin kapı dışarı edilmesi gibi yanlış yolların benimsenmesi yüzünden bugünkü hal ortaya çıkmışıır ${ }^{117}$."

Mezkûr yazının devam eden satırları dikkate alındığında; medresenin içinde bulunduğu durumun hiç de iç açıcı olmadığı, gelinen bu aşamada medreselerin ıslahının gerekliliğine ilişkin olarak sağduyu sahibi mütefekkirler tarafından uzun uzun makaleler, lâyihalar ve programların hazırlandığı ve bu çalışmaları yapanların medreselerin ıslahına ilişkin planların uygulamaya geçirilmesini arzu ettikleri vurgulanmıştır. Hazırlanmış olan bu programlar Meclis-i Mesâlih-i Talebe tarafından etraflıca tartışılış; daha önce gerçekleştirilen ıslahat kapsamında yeni dershanelerin açılması ve medrese programlarına yeni ilimlerin ilave edilmesi o dönem için bir yenilik sayılsa da; bu uygulamaların yeterli olmadığı belirtilerek, daha geniş ve daha esası ı bir planlamaya ve teşkilata intiyaç duyulduğu ifade edilmiştir. Meclis-i Mesalih-i Talebe sadece durum tesbiti yapmakla kalmamış; medreselerin ıslahı konusunda uygulanması müşkül olan projeler hazırlayarak vakit kaybetmek yerine, uygulanması imkân dâhilinde olan bir usul ve teşkilat yapısını içerecek ve vakit kaybetmeksizin tatbik edilecek bir lâyihanın hazırlandığını beyan etmiştir. Bu lâyiha ile, muhtemelen Medresetü'I-Mütehassısîn Nizamnâmesi kasdedilmektedir. Gerek Nizamnâme ve gerekse nizamnâmenin esbâb-ı mûcibesi mesâbesindeki bahse konu yazının temel felsefesi; "her şeyden evvel yetenek sahibi; muktedir ve mütehassıs müderris ve muallimlere ihtiyaç duyulduğu," hususudur. Bu ihtiyacın giderilmesi için hazırlanan Nizamnâme ile eğitim süresi 4 yıl olan Medresetü'lMütehassısîn'in açılması hükme bağlanmıştır. Ancak bu nizamnâme uygulamaya geçirilememiş, kısa bir süre sonra Tûbâ Ağacı Nazariyesi'nden vazgeçilerek Mustafa Hayri Efendi'nin şeyhülislamlık makamına getirilmesiyle birlikte Satı Bey'in geliştirmiş olduğu; eğitimin ilkokuldan başlayarak yukarıya doğru yapılandırıldığı nazariye uygulamaya geçirilmiştir.

117 iMMA, MMTD, nr. 2203, s.3.

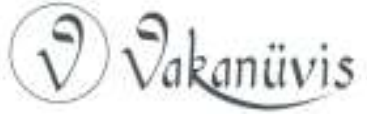


II. Meşrutiyetle birlikte medreselerde gerçekleştirilmesi planlanan reformun büyük heyecanla karşılandığı görülse de; yapılacak reformun niteliğine ve usulüne ilişkin farklı görüşler ortaya çıkıyordu. Bu farklı görüşler "ilmiye sınıfı içinde muhafazakâr ve reform yanlısı ulemâ arasındaki değişen güç ilişkilerini yansıtıyordu ${ }^{118}$." Şeyhülislâm Mustafa Hayri Efendi döneminde ıslahatta etkili olan sınıf reform yanlısı ulemâ iken, gelenekçilikle modernizm arasında orta yolu tutan íslamcılardan sayılan Şeyhülislâm Musa Kazım Efendi ${ }^{119}$ döneminde de aynı anlayışın sürdürülmesine çaba sarf edilmişse de muhafazakâr eğilimin etkisi hissedilmiştir. Reform yanlısı ulemânın etkisiyle medreseler, batı tarzı mektepler model alınmak suretiyle dönüştürülerek esaslı bir şekilde yapılandırılmaya çalışılırken, muhafazakâr eğilimli ulemâ geleneksel medresenin korunmasına; Türkçülük fikriyatını benimsemiş çevreler ise değişik gerekçelerle ıslahatı engellemeye çalışmışlardır. Özellikle Şeyhülislâm Mustafa Hayri Efendi tarafından gerçekleştirilen ıslahata, başta İttihat Terakki Fırkası olmak üzere Türkçülük ideolojisini benimsemiş olanlar ihtiyatla yaklaşmış; zahirde ıslahatı destekliyor görünseler de gerçekleştirilen ıslahat kapsamında medreselerde Arapça eğitim verilmesini Türkçülüğe bir darbe telakki etmişlerdir ${ }^{120}$. Başta Ziya Gökalp olmak üzere İttihat Terakki Fırkasının temkinli ve ikircikli yaklaşımları nedeniyle ıslahatın sağlıklı bir şekilde uygulamaya geçirilmesine imkân bunamadığı anlaşılmaktadır ${ }^{121}$.

Mustafa Hayri Efendi'nin şeyhülislâmlık görevini deruhte etmesiyle birlikte medreselerde başlatılan ıslahât çalışmaları; adı geçen şeyhülislamın selefleri tarafından da devam ettirilmiş, medreselerin Tevhid-i Tedrisât Kanunu ile kapatılmasına kadar geçen 10 yıllık süreçte değişik kurul ve komisyonlar marifetiyle yoğun çalışmalar gerçekleştirilmiştir. Bu bağlamda 4 Mart 1334/1918 tarihinde yayımlanan 'Dâire-i Meşîhat'ta Bir Dârü'l-Hikmeti'l-islâmiyye Te'sisi ve

\footnotetext{
118 Amit Bein, Osmanlı Ulemâsı ve Türkiye Cumhuriyeti-Değişimin Failleri ve Geleneğin Muhafızları, çev. Bülent Üçpunar, Kitap Yayınevi, İstanbul, 2013, s.77.

119 Hilmi Ziya, Ülken, Türkiye'de Çağdaş Düşünce Tarihi, Türkiye İş Bankası Yay., 3.bs., İstanbul, 2015, s.396-397.

${ }^{120}$ Ali Suat Ürgüplü, Şeyhülislam Ürgüplü Mustafa Hayri Efendi'nin Meşrutiyet, Büyük Harp ve Mütareke Günlükleri(1909-1922), Türkiye İş Bankası yay., İstanbul, 2015, s.381.

121 Ürgüplü, a.g.e., s.378-387.
}

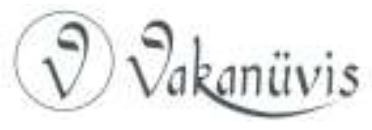


Meclis-i Meşâyih Teşkilatının Tevsi'iyle Müftülerin Sınıf ve Maâşâtı Hakkında Kanun'un Esbâb-ı Mucibe Layihası'yla kurulan Dârü'lHikmeti'l-islâmiye'nin kuruluş amaçlarından birisinin "...medârisi tensîk ve ıslah gibi mekâsîd-i mühimmenin takip ve istihsâli... ${ }^{122 " ~ o l m a s ı ~ d i k k a t ~}$ çekmektedir. Mezkûr kanunla, medreseleri düzene sokma ve iyileştirme yönündeki amaçların takibi ve bu amaçların gerçekleştirilme görevi adı geçen teşkilatın uhdesine verilmiştir.

Netice itibariyle, yukarıda sıralanan pek çok iyileştirici düzenlemelere ve girişimlere 3 Mart 1924 Tevhid-i Tedrisât Kanunu ile medreselerin kapatılmasına kadar geçen sürede yoğun bir şekilde teşebbüs edilmiş, medreselerin kapatılmasından sonra da, din öğretimi misyonunu üstlenen eğitim kurumlarıyla ilgili pek çok yapısal ve yasal düzenlemelerle ilgili çalışmalara devam edilmiştir.

\section{Sonuç}

Altı asırlık kurumsal geçmişe ve birikime sahip olan Osmanlı medreseleri, kuruluşundan kapatılmasına kadar geçen süreçte gerek teşkilat yapısı, gerekse eğitim-öğretim itibarıyla pek çok düzenlemelere ve gelişmelere sahne olmuştur.

Medreseler vakıflar eliyle faaliyet yürüten eğitim kurumları olması nedeniyle nev-i şahsına münhasır yarı özerk müesseselerdir. İmparatorluk coğrafyasının genişliğinin yanında dinî ve etnik âidiyetlerin çokluğu da dikkate alındığında bu müesseselerin tek tip eğitim kurumları gibi ele alınarak değerlendirilmesi ve herhangi bir medreseye ilişkin gözlem ve tesbitlerin tüm medreselere teşmil edilmesi doğru bir yaklaşım olamaz.

Medreseler için ileri sürülen bozulma ve gerilmenin başlangıcını, tarihte yaşanmış bir olaya bağlayarak doğrusal bir hareketle çöküşe doğru evrildiğini dile getiren araştırmaların tamamının birbirinin tekrarı mahiyetinde olduğu müşahade edilmektedir. Bu çalışmalarda özellikle Kanûnî'nin ölümünden sonra başlatılan bozulma ve gerilemenin üç asrı aşkın süre boyunca devam ettiğinin iddia edilmesi de mâkul görülmemektedir.

${ }^{122}$ Ceride-i Ilmiye (Ci), S.36, s.1058.

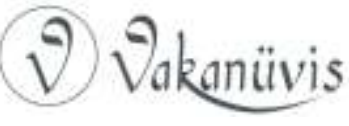


Medreselerin bulundukları coğrafyanın dinî ve etnik yapısı ile toplumun sosyal ihtiyaçları dikkate alınmadan ve bu ihtiyaçların ne kadarının medreseler tarafından karşılandığına dair tesbitler yapılmadan, muâdil olmayan eğitim kurumlarıyla medreselerin mukayeseye tâbî tutulması uygun olmayacağı gibi; konjonktür, sosyal hayatın dinamik yapısı ve intiyaçların değişkenliği nedeniyle eğitimsel hedeflerde güncellemeye gidilmesi ya da ortaya çıkan arızaların giderilmesi amacıyla mevzuat hazırlanarak ıslah faaliyetlerine girişilmesinin de medreselerdeki bozulmaya delil gösterilmesi isabetli bir yaklaşım olmayacaktır. Kaldı ki günümüz eğitim sisteminde de değişik gerekçelerle ve sık aralıklarla düzenleyici işlemlerin hayata geçirildiği; eğitim kurumlarının gerek kurumsal yapısına gerekse eğitim-öğretimin uygulanmasına ilişkin pek çok düzenleyici tedbirlerin alındığı bir vâkıadır.

Dolayısıyla altı asırlık medrese müktesebatına ve tecrübesine bütüncül bir yaklaşımla bakmak; yapılacak değerlendirmeleri bağlamından koparmadan ve dönemsel özellikleri dikkate alarak gerçekleştirmek doğru bir yöntem olacaktır. Özellikle II. Meşrutiyet döneminde medreselerde gerçekleştirilmeye çalışılan ıslahatın dönem itibarıyla ileri ve modern sayılacak düzenlemeler içerdiği, ancak dönemin olağanüstü şartları nedeniyle akâmete uğradığı hususu gözden kaçırılmamalıdır. Hayata geçirilmeye çalışılan ıslahat faaliyetlerinin niteliği ve pratiği incelendiğinde Osmanlı tarihinin en zor dönemi olan 20. yüzyılın ilk çeyreğinde medreselerin değişime ve yenileşmeye açık bir yapıya sahip olduğu görülecektir.

Bu itibarla Osmanlı medreselerini, ne toptancı bir yaklaşımla her türlü tenkit ve eleştiriden müstağni kılarak yüceltmek; ne de Kanûnî'den sonraki yaklaşık üç asırlık süreci bozulma ve gerileme dönemi olduğu isnâd ve gerekçesiyle tamamen işlevsiz bir kurum konumuna indirgemek doğru bir yaklaşım olmayacaktır.

\section{Kaynakça}

\section{Kitaplar}

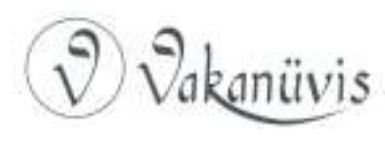


Adıvar, A. Adnan, Osmanlı Türklerinde Ilim, Remzi Kitabevi, 4. Baskı, İstanbul, 1982.s.126.

Alkan, Mehmet Ö., Tanzimat'tan Cumhuriyet'e Modernleşme Sürecinde Eğitim İstatistikleri (1839-1924), T.C. Başbakanlık Devlet İstatistik Enstitüsü, Ankara, Kasım-2000.

Atay, Hüseyin, Osmanlılarda Yüksek Din Eğitimi: Medrese Programlarıicazetnâmeler, Islahat Hareketleri, Dergah Yayınları, İstanbul, 1983;

Atâyi, Atâullah Nev'izâde; Zeyl-ü Şakâyık li-Atâyi, y.y., t.y.

Ayverdi, İlhan, Kubbealtı Lugatı: Asırlar Boyu Tarihi Seyri Içinde Misalli Türkçe Sözlük, Kubbealtı yay., (gözden geçirilmiş) 3.bs., İstanbul, 2008.

Baltacı, Cahid, XV-XVI Yüzyıllarda Osmanlı Medreseleri, IFAV yay., 2c., 2.bs., İstanbul, 2005, C:I.

Bein, Amit, Osmanlı Ulemâsı ve Türkiye Cumhuriyeti-Değişimin Failleri ve Geleneğin Muhafızları, çev. Bülent Üçpunar, Kitap Yayınevi, İstanbul, 2013.

Beysanoğlu, Şevket, Ziya Gökalp'ın Ilk Yazı Hayatı(1894-1909), Diyarbakır’ı Tanıtma Derneği Neşriyatı, İstanbul, 1956.

Bolay, S. Hayri, Osmanlılar'da Düşünce Hayatı ve Felsefe, Akçağ yay., Ankara, 2005.

Bowen, Harold, Türkiye Hakkında Ingiliz Tetkikleri, çev. Orhan Burian, TTK. Yay., Ankara, 2011.

Çetintaş, Ibrahim, "Saçaklızâde Muhammed Mar'aşî", Doğu'dan Batı'ya Düşüncenin Serüveni, edit. Bayram Ali Çetinkaya, 10c., İnsan yay., İstanbul, 2015, C:VIII, s.971-990).

Dilbaz, Mahmut, Askeri Modernleşmenin Dinî Müdafaası-Es'ad Efendinin Şerhli Es-Sa'yü'l-Mahmûd Tercümesi, Dergah Yay., İstanbul, 2014.

Düstur, Tertib-i Sânî, c.2, Matbaa-ı Osmaniye, Dersaâdet, 1330, s.127-138.

Emrullah Efendi, Osmanlı Ittihad ve Terakki Cemiyyetinin Bin Üç yüz Yirmi Yedi Senesi Dördüncü Konferansında Tanzim Olunan Siyasi Programa Dair İahnâme, Matbaa-ı Hayriyye, Kostantiniyye,1330.

Ergin, O. Nuri, Türkiye Maarif Tarihi, C.I-II., Eser Matbaası, İstanbul, 1997.

Ergün, Mustafa, II. Meşrutiyet Devrinde Eğitim Hareketleri-(1908-1914), Ocak Yay., Ankara, 1996.

Georgeon, François, Sultan Abdülhamid, çev.Ali Berktay, Homer Kitabevi, İstanbul, 2006.

Günüç, Fevzi, Türk Kültür ve Medeniyet Tarihinde Fatih Külliyesi-I, edit. Hüseyin Kutlu, İBB Kültür AŞ.yay., İstanbul, 2007.

Halaçoğlu, Yusuf, XIV-XVII. Yüzyıllarda Osmanlılarda Devlet Teşkilâtı ve Sosyal Yapı, T.T.K. Yay., 7.bs., Ankara, 2014.

Hocaoğlu, Mehmet, Abdülhamit Han'ın Muhtıraları(Belgeler), Oymak yay., İstanbul, ty.

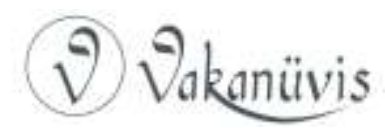


IImiye Salnâmesi, Matbaa-ı Amire, Dârü'I-hilâfeti'l-aliyye, 1334.

İnalcık, Halil, Osmanlı Imparatorluğu-Klasik Çağ (1300-1600), Çev. Ruşen Sezer, Yapı Kredi Yay., İstanbul, 2003.

İzgi, Cevat, Osmanlı Medreselerinde Illim, 2c., İz Yay., İstanbul, 1997.

Kânunnâme-i Âl-i Osman, Tarih-i Osmanî Encümeni Mecmuasının ilâvesi, Ahmed ìssan Şürekâsı Matbaacılık Osmanlı Şirketi, İstanbul, 1329.

Karaarslan, Nasuhi Ünal, XVIII. Asrın Ortalarına Kadar Türkiye'de Ilim ve IIImiyeye Dair Bir Eser- Kevâkib-i Seb'a Risâlesi, TTK. Yay., Ankara, 2015.

Karal, Enver Ziya; Selim III'ün Hat-tı Hümayunları-Nizam-ı Cedit-(17891807), TTK. Yay. 2.bs., Ankara, 1988.

Kâtip Çelebi, Mizânüll-Hakk fí Ihtiyâri'l-Ehak, 2.bs., Ali Rıza Efendi Matbaası, İstanbul, 1286.

Koçer, Hasan Ali, Türkiye'de Modern Eğitimin Doğuşu (1773-1923), Uzman Yay., Ankara, 1987.

Koçi Bey, Koçi Bey Risâlesi, Kütüphane-i Ebu'z-Ziya, 1.bs., Kostantiniyye, 1303.

Kodaman, Bayram, Abdülhamid Devri Eğitim Sistemi, T.T.K. Yay., Ankara, 1999.

Kurt, Yılmaz, Koçi Bey Risâlesi, Akçağ Yay., 3.bs., Ankara, 2011.

Kütükoğlu, Mübahat S. , Lütfü Paşa Âsafnâmesi (Yeni Bir Metin Tesisi Denemesi), İstanbul Üniversitesi Edebiyat Fakültesi Basımevi, İstanbul, 1991.

Mardin, Şerif, Türkiye'de Toplum ve Siyaset, İletişim yay., 13.bs., İstanbul, 2006.

Marsilli, Graf, Osmanlı Imparatorluğunun Zuhur Ve Terakkisinden Inhitatı Zamanına Kadar Askeri Vaziyeti, çev. M. Kaymakam Nazmi, Büyük Erkânı Harbiye Matbaası, Ankara, 1934.

Öz, Mehmet, Kanun-i Kadimin Peşinde-Osmanlı'da Çözülme ve Gelenekçi Yorumcuları, Dergâh Yayınları, 6.bs., İstanbul, 2009.

Özyılmaz, Ömer, Osmanlı Medreselerinin Eğitim Programları, Kültür Bakanlığı yay., Ankara, 2002.

Sarıkaya, Yaşar, Medreseler ve Modernleşme, İz Yayıncılık, İstanbul, 1997.

Taslaman, Caner, Küreselleşme Sürecinde Türkiye'de islam, İstanbul Yay., 8.bs., İstanbul, 2014.

Taşköprîzâde Ahmed ibn Mustafa, Tercüme-i Şakâyık-ı Nu'mâniyye, y.y., t.y.

Ülken, Hilmi Ziya, Türkiye'de Çağdaş Düşünce Tarihi, Türkiye İş Bankası Yay., 3.bs., İstanbul, 2015.

Ünal, Uğur; Birbudak, Togay S., İstanbul Dârülmuallimîni(1848-1924), Atatürk Kültür, Dil ve Tarih Yüksek Kurumu, Ankara, 2013. 
Ürgüplü, Ali Suat, Şeyhülislam Ürgüplü Mustafa Hayri Efendi'nin Meşrutiyet, Büyük Harp ve Mütareke Günlükleri(1909-1922), Türkiye işs Bankası yay., İstanbul, 2015.

Uzunçarşııı, İsmail Hakkı; Osmanlı Devletinin IIlmiye Teşkilâtı, T.T.K. Yayınları, 4. bs., Ankara, 2014.

Yavuz, Hilmi, Türkiye'nin Zihin Tarihi, Timaş Yay., 3.bs., İstanbul, 2013.

\section{Makaleler}

Akün, Ömer Faruk, "Koçi Bey", TDV islam Ansiklopedisi, İstanbul, 2002, C:XXVI., (s.143-148)

Alkan, Mehmet Ö., "Osmanlı İmparatorluğunda Modernleşme ve Eğitim", Türkiye Araștırmaları literatür Dergisi(Türk Eğitim Tarihi),BiSAV yay.,c.6, S.12, istanbul, 2008, (s.9-84).

Atay, Hüseyin, "Medreselerin Gerilemesi", A.Ü.I.F. Dergisi, Ankara, 1981, S.24, (s.15-56).

Atay, Hüseyin, "Medreselerin Islahatı", A.Ü.i.F. Dergisi, Ankara,1982, S.25, (s.1-43).

Bakır, Kemal, "Il. Meşrutiyet Döneminde Milli Seçkincilik ve Eğitim: Emrullah Efendi Tûba Ağacı Nazariyesi", Doğu Batı-Düşünce Dergisi, C:I., S.45, Mayıs-Haziran-Temmuz, 2008, s.197-213).

Çetin, Atila, “Medreselerin Islahına Dâir Safvet Paşa'nın Düşünceleri ve Bir Arizası", Türk Dünyası Dergisi, Kasım-1994, No:95, s.16-18)

Emin Bey, "Tarihçe-i Tarîk-i Tedris", ilmiye Salnâmesi, Matbaa-ı Amire, Dârü'l-hilâfeti'l-aliyye, 1334, (s.642-651).

Ergün, Mustafa, -"Batılılaşma Dönemi Osmanlı Eğitim Sistemine Mukayeseli Bir Bakış", Osmanlı Dünyasında Bilim ve Eğitim-Milletlerarası Kongresi Tebliğleri (Istanbul 12-15 Nisan 1999), Der. H.Yavuz Türkoğlu, îRCiCA yay., İstanbul, 2001.

Hızlı, Mefail, "Anadolu'daki Osmanlı Medreseleri: Bir İcmal", Türkiye Araştırmaları Literatür Dergisi, (2004) C:II., S.4, (s.371-409).

Ipşirli, Mehmet, "Osmanlı ilmiye Mesleği Hakkında Gözlemler (XVI-XVII. Asırlar)", Osmanlı Araştırmaları VII-VIII, edit. I.E. Erünsal, C.Ferrard, C.Woodhead, ìstanbul, 1988, s.273-285).

Sarıkaya, Yaşar, "Osmanlı Medreselerinin Gerileme Meselesi: Eleştirel Bir Değerlendirme Denemesi", ìslâmî Araştırmalar Dergisi, 1999, No:3, (s.23-39).

Yazıcı, Nesimi, "Osmanlıların Son Döneminde Din Görevlisi Yetiştirme Çabaları üzerine Bazı Gözlemler", Diyanet Dergisi, S.4, C.XXVII, Ankara, 1991,( s.55-123).

Yıldız, Hasan, "Osmanlı Medrese Eğitim Sisteminde Karar Organı: Meclis-i Mesâlih-i Talebe Ve Müfredât Programlarını Hazırlama Sürecindeki Rolü (II. Meşrutiyet Dönemi Örneği)", İstanbul Üniversitesi Türkiyat Mecmuası, 2018, c.28, S.2, s.255-275.

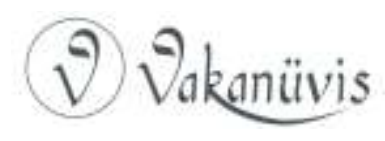




\section{Gazeteler}

Müftüzâde: “istanbul Medreseleri-II”, Sebilürreşâd, S.542-543, C:XXI., (s.176-177).

Tunalı Hilmi; "Medreseler Kongresi”, Sırâtımüstakîm, S.54, C:III, (s.25-28).

Beyânü'l-Hak, S.15, s.322-324.

Beyânü'l-Hâk, S.47, s.11.

Ceride-i îlmiye (Ci), S.36, s.1058.

Sırâtımüstakîm, S.76, c.3, s.379

Sırâtımüstakîm, S.54, c.3, s.25-28.

Arşiv Belgeleri

İstanbul Müftülüğü Meşîhat Arşivi (IMMA), Meclis-i Mesâlih-i Talebeye Mahsus Müsvedde Varakaları (MMTMMV):

IMMA, MMTMMV, Defter nr. 2060.

IMMA, MMTMMV, Defter nr. 2061.

iMMA, MMTMMV, Defter nr. 2064.

İstanbul Müftülüğü Meşîhat Arşivi (IMMA), Meclis-i Mesâlih-i Talebe Defterleri (MMTD):

IMMA, MMTD, Karar, Defter nr.2203. 